\title{
Payout Taxes and the Allocation of Investment
}

\section{Citation}

Becker, Bo, Marcus Jacob, and Martin Jacob. "Payout Taxes and the Allocation of Investment." Journal of Financial Economics (forthcoming).

\section{Permanent link}

http://nrs.harvard.edu/urn-3:HUL.InstRepos:9491450

\section{Terms of Use}

This article was downloaded from Harvard University's DASH repository, and is made available under the terms and conditions applicable to Open Access Policy Articles, as set forth at http:// nrs.harvard.edu/urn-3:HUL.InstRepos:dash.current.terms-of-use\#OAP

\section{Share Your Story}

The Harvard community has made this article openly available.

Please share how this access benefits you. Submit a story.

Accessibility 


\title{
Payout Taxes and the Allocation of Investment*
}

\author{
Bo Becker \\ Harvard University and NBER \\ bbecker@hbs.edu \\ Marcus Jacob \\ WHU - Otto Beisheim School of Management \\ marcus.jacob@whu.edu \\ Martin Jacob \\ WHU - Otto Beisheim School of Management \\ martin.jacob@whu.edu
}

This draft: April, 2012

\begin{abstract}
When corporate payout is taxed, internal equity (retained earnings) is cheaper than external equity (share issues). If there are no perfect substitutes for equity finance, payout taxes may therefore have an effect on the investment of firms. High taxes will favor investment by firms who can finance internally. Using an international panel with many changes in payout taxes, we show that this prediction holds well. Payout taxes have a large impact on the dynamics of corporate investment and growth. Investment is "locked in" in profitable firms when payout is heavily taxed. Thus, apart from any level effects, payout taxes change the allocation of capital.
\end{abstract}

JEL No. G30, G31, H25.

- We thank Chris Allen and Baker Library Research Services for assistance with data collection. We are grateful to Tor-Erik Bakke, Raj Chetty, Fritz Foley, Jochen Hundsdoerfer, James Poterba, Kristian Rydqvist, Richard Sansing, William Schwert (the editor), Toni Whited, an anonymous referee, and seminar participants at European Business School, Harvard Business School, Harvard Economics Department, the UNC Tax Symposium, the Nordic Workshop on Tax Policy, University of Wuerzburg and Public Economics, the Stockholm Institute for Financial Research (SIFR), and the 2012 American Finance Association Meeting for helpful comments. 


\section{Introduction}

Corporate payout, in the form of dividends or as repurchases of shares, is subject to taxation in most countries. Such taxes on corporate payout drive a wedge between the cost of internal and external equity (retained earnings and equity issues, respectively). Higher payout taxes raise the cost of capital for firms using external equity to fund investment relative to those using internal equity. Therefore, higher payout taxes are expected to "lock in" investment in profitable firms, at the expense of firms with investment opportunities which would require external equity financing to undertake.

The empirical relevance of this simple prediction has not been well tested. Despite the large amount of theoretical and empirical research about the effect of dividend taxes on the level of investment and on the valuation of firms (see, e.g., Auerbach, 1979a, 1979b; Bradford, 1981; Chetty and Saez, 2010; Feldstein, 1970; Guenther and Sansing, 2006; Harberger, 1962; King, 1977; Korinek and Stiglitz, 2009; Poterba and Summers, 1984 and 1985), little is known about the effects of such taxes on the allocation of investment across firms. Yet, the theoretical prediction is very clear: higher payout taxes will increase the wedge between the cost of internal and external equity, and firms with more costly external financing will exhibit greater investment cash flow sensitivities. Put differently, payout taxes favor investment financed by retained earnings over investment financed by equity issues. This can matter for the productivity and nature of investment if a) debt finance is an imperfect substitute for equity (in other words, if the Miller Modigliani propositions do not hold), b) different firms have different investment opportunities, c) the marginal investor is subject to taxation, and d) firms make equity payouts while the tax is in effect. All these conditions have empirical support. ${ }^{1}$ But are such frictions important enough for this to matter in practice for investment levels? This paper aims to test the extent to which the "lock in" effect of payout taxes matters empirically.

There are several challenges in testing how payout taxes affect the cross-firm allocation of investment. First, large changes in the US tax code are rare. The 2003 tax cut has provided a suitable natural experiment for testing how dividend levels responded to taxes (see Chetty and Saez, 2005 and Brown, Liang, and Weisbenner, 2007), but investment is a more challenging dependent variable than dividends, so the experiment may not provide sufficient statistical power for examining investment responses. First, unlike dividends, investment is imperfectly measured by accounting data that, for

\footnotetext{
${ }^{1}$ Regarding the imperfect substitutability between debt and equity, see e.g. Myers (1977), Jensen and Meckling (1976). Regarding the variation in investment opportunities across firms, see e.g. Coase (1937) and Zingales (2000). Firms with limited access to internal equity may include entrepreneurial firms and firms with strong growth opportunities. Regarding the taxability of the marginal investor, see e.g. our Section 4.3. Note also that in many countries outside the U.S. and the U.K. (for example, in Germany and Austria) investment funds managing private investors' money are ultimately taxed like private investors. Regarding payout, many firms pay dividends or repurchase shares every year. Others may plan to do so in the future. Korinek and Stiglitz (2010) consider firms' ability to time their payout around tax changes.
} 
example, leave out many types of intangible investment such as that in brands and human capital. This means that available empirical proxies (e.g. capital expenditures) are noisy estimates of the true variable of interest. Second, much investment is lumpy and takes time to build, so any response to tax changes is likely slow and more difficult to pinpoint in time. This suggests that a longer time window may be necessary (the payout studies used quarters around the tax change). Third, however, investment is affected by business cycles and other macro-economic trends, so extending the window around a single policy change introduces more noise from other sources, and may not provide better identification.

We address these challenges by using an international dividend and capital gains tax data set covering 25 countries over the 19-year period 1990-2008 (Jacob and Jacob, 2011). This data set contains fifteen substantial tax reforms and 67 discrete changes in the dividend or capital gains tax rate. With so many tax changes, we have sufficient variation to study the effects of payout taxes on the investment allocation. We use this tax data base to test if the allocation of investment across firms with and without access to internal equity depends on payout taxes. We first run non-parametric (NP) tests that contrast the investment by the two groups of firms around tax reforms. We focus on events where payout taxes changed by at least three percentage points and compare the five years preceding the tax change with the two years following it. There are 15 events with payout tax reductions. The mean tax drop is 9.8 percentage points (median 5.5). There are 14 tax increase events with a tax change of 8.4 percentage points (median 5.6). We sort firms into quintiles of the ratio of cash flow to assets in each country-year cell. We then calculate average investment over lagged assets for each quintile. There is no trend in investment for any of the quintiles during the five year period preceding the tax events. After the tax cuts, we observe a significant convergence of the investment rate of high and low cash flow firms (top and bottom quintiles). In other words, firms with limited internal equity increase their investment relative to firms with plenty of internal equity. This is consistent with the tax wedge theory, and suggests that low taxes favor firms with limited access to internal equity. In contrast, following increases in payout taxes there is a divergence of investment of high and low cash flow firms. The estimated effects appear large in both sets of tax reforms. On average, the difference in investment between low and high cash flow firms increases from $5.33 \%$ (of assets) to $7.59 \%$ following a payout tax increase - a $42 \%$ increase. When payout taxes are cut, the difference in investment falls from $7.27 \%$ to $5.54 \%$ - a decrease by $31 \%$. In other words, for the typical large tax change, a large quantity of investment is estimated to get displaced. When taxes go up, investment flows from firms with limited access to internal equity to those with more internal equity, and vice versa for tax reductions. These non-parametric results are consistent with the predictions of the tax wedge theory.

Because the panel data set contains multiple tax change events, we can estimate not just the mean treatment effect of a tax change, but also ranges. Only two (three) of the 15 (14) tax decreases (increases) 
have difference-in-difference effects that are in conflict with our hypothesis. The other estimates agree with the tax wedge hypothesis, and many point estimates are large: one third of tax decreases events reduce the difference in the investment rate of high and low cash flow firms by at least 2.5 percentage points. About $40 \%$ of the tax raises are associated with a point estimate for the increased wedge between high and low cash flow firms by more than 2.5 percentage points. ${ }^{2}$ In other words, the effect of tax changes on the relative investment of firms varies quite a bit across events, and is sometimes large. We can also use the individual difference-in- difference point estimates to do non-parametric tests. For example, a sign test of the frequencies with which estimates are positive and negative suggest that we can reject that an increase and a decrease of the investment rate difference are equally likely after a tax increase (decrease) at the $5 \%(1 \%)$ level of statistical significance.

We also use linear regressions to produce parametric estimates of the effect of taxes on relative investment of rich and poor firms. Unlike the non-parametric tests, the regressions use data from all years, and can integrate both tax increases and decreases in the same specifications. The two methods also put different weight on observations (equal-weighting tax changes vs. equal-weighting firm-years), For our baseline tests, we regress investment on firm controls, fixed effects for firms and for country-year cells, and the interaction of the payout tax rate with cash flow. Thanks to the panel structure of the data set, we can allow the coefficient on cash flow to vary across countries and years, in essence replicating the identification strategy of the many studies exploiting the 2003 tax cut in the US, but for the whole panel of 25 countries times 19 years. The estimated coefficient for the tax-cash flow interaction variable is consistently positive and significant. In other words, the higher payout taxes are, the stronger is the tendency for investment to occur where cash flows are high. As predicted by the tax wedge theory, payout taxes "lock in" investment in firms generating earnings and cash flow. The estimated magnitudes are large. For example, going from the $25^{\text {th }}$ percentile of payout tax $(15.0 \%)$ to the $75^{\text {th }}$ percentile $(32.2 \%)$ implies that the effective coefficient on cash flow increases by 0.029 , an increase by $33 \%$ over the conditional estimate at the $25^{\text {th }}$ percentile. Like the NP results, this implies that payout taxes have an important effect on the allocation of capital across firms.

We report extensive robustness tests for these results. For most tests, we report regression results with three alternative tax rates, with similar results. The results also hold for alternative measures of the ability to finance out of internal resources (e.g. net income instead of cash flow), as well as when controlling for the corporate income tax rate and its interaction with cash flow. We also collect economic policy controls from the World Development Indicators (World Bank 2010). This is to address endogeneity concerns, i.e.

${ }^{2}$ Not all tax changes produce point estimates in the predicted direction. This is what we would expect if the effect on investment is difficult to estimate, and in line with the motivation for our empirical design: we need a multitude of events because the statistical precision using a single tax change is relatively low. 
to ensure that tax changes are not just fragments of wider structural changes in an economy that change firms' investment behavior around tax reforms. This test shows that payout tax changes appear to have their own very unique and economically significant effect on the allocation of investment (assuming we have identified the relevant set of policy variables). We further ensure robustness to alternative regression frameworks and specification strategies. We also ensure robustness of our model predictions to cash investments, and we address concerns about the potential impact of measurement error in investment opportunities.

We also examine cross-sectional differences in the response to taxes. We attempt to identify firms whose marginal source of funding is likely to be external equity based on three measures. First, we consider predicted equity sales. Second, we look at historical equity issuance. We exploit the fact that such issuance is persistent, so that classifying firms by recent equity issuance likely indicates their ability to issue in the future. ${ }^{3}$ Third, we classify firms within the two lowest quintiles of the age and the size distribution in one country-year as more likely to use external equity (Hadlock and Pierce, 2010). For all three classifications, there is a sizable difference in the effect of taxation on the marginal source of funds for investment between old view firms and new view firms. The cash flow coefficient is sensitive to tax rates only for firms that are more likely to use external equity. This confirms the mechanism behind the differential responses of investment to tax rates that we have documented earlier.

Finally, we examine how quantities of equity raised respond to taxes. If our identifying assumptions are valid, and if we have identified real variation in the effective taxation as perceived by firms, we would expect to see a drop in equity issuance when taxes go up. We find exactly this: When taxes are high, equity issuance tends to be low. This supports the interpretation that the tax variation we pick up is meaningful.

Our results are related to the debate about the impact of payout taxes on the level of investment between the "old view" (Harberger, 1962, 1966; Feldstein, 1970; Poterba and Summers, 1985) and the "new view" (Auerbach, 1979a; Bradford, 1981; King, 1977). This debate can be understood in terms of different assumptions about the marginal source of investment financing. To simplify, the old view assumes that marginal investment is financed by equity issues, so that payout taxes raise the cost of capital and reduce investment. The new view assumes that marginal investment is financed by retained earnings, so that payout taxes do not reduce investment. In practice, firms are likely to differ in their

\footnotetext{
${ }^{3}$ In our data, firms that issued any equity in the previous year are 3.9 times as likely to issue again next year. Firms issuing more than 5\% of assets over the last year are 7.7 times as likely to do so again this year. These numbers probably reflect capital needs as well as access to the market. There are several possible reasons for this. Issuing costs are high for equity (see Asquith and Mullins, 1986 and Chen and Ritter, 2000). However, some firms find it less costly to issue equity, for example because they have a favorable stock valuation (see Baker, Stein, and Wurgler, 2003).
} 
ability to finance investment with internal resources (e.g. Lamont, 1997). If they do, the tax rate will affect the allocation of investment.

Our results have three main implications. First, it appears that payout taxes influence the allocation of capital across firms. High taxes lock in capital in those firms that generate internal cash flows, ahead of those firms that need to raise outside equity. If firms have different investment opportunities, this means that tax rate changes alter the type of investments being made. For example, high payout taxes may favor established industries. We consider the allocation across firms an important topic in itself, but there may also be some suggestive implications for aggregate investment. Our results generally point to the relevance of payout taxes for investment (for a subset of firms). Second, the effect of payout taxes is related to both access to the equity market and governance. Firms that rely on access to equity markets as a source of finance, "old view" firms, are the most affected by tax changes. Firms whose only source of equity finance is internal are less affected by taxes, as predicted by the "new view". A final source of heterogeneity is governance. Firms where decision makers have low financial stakes are less affected by tax changes, reflecting their propensity to make investment decisions for reasons unrelated to the cost of capital. Third, the relation between cash flow and investment (see e.g. Fazzari, Hubbard, and Petersen, 1988; Kaplan and Zingales, 1997) appears to partially reflect the difference in the after-tax cost of capital between firms with and without access to inside equity.

\section{The model - payout taxation and investment decisions}

We formalize our predictions in a simple one-period model (similar to, but simpler than, Lewellen and Lewellen, 2006). We consider a firm that has the opportunity to invest $\$ 1$ at time 1 and receive $1+\pi$ at time $2 .{ }^{4}$ The net return $\pi$ is subject to corporate tax at the rate $\tau_{c}$. In period 2 , the firm returns all cash to investors. We assume that all payout of profits, be it through dividends or share repurchases, is fully taxable at corporate payout tax rate $\tau_{\mathrm{p}}$. If the firms distributes cash only as dividends, $\tau_{\mathrm{p}}$ equals the tax rate on dividends $\tau_{\mathrm{div}}$. If the firm uses share repurchases to return capital to investors, $\tau_{\mathrm{p}}$ equals the tax rate on capital gains $\tau_{\mathrm{cg}}$, as long as the tax basis is zero (we generalize this below). Returning paid-in capital has no tax consequences. For simplicity, we refer to this payout as a dividend. Investors have access to an investment of similar risk yielding a rate of return $\hat{r}$, taxed at rate $\tau_{i}$ on this investment. Let $r=\widehat{r}\left(1-\tau_{i}\right)$ represent the after-tax return on investors' alternative investment.

The model predictions depend on the firm's availability of internal funds to finance the investment. We consider two cases: a firm without and with sufficient internal resources (retained earnings) to fund

\footnotetext{
${ }^{4}$ The investment opportunity can be thought of as an investment in the firm's production technology. The model may apply to financial assets, including cash, but subject to possible caveats. We discuss this in Section 2.2 below.
} 
investment. In the first case, the firm has zero cash and must issue equity in order to undertake the investment. ${ }^{5}$ This assumption about the marginal source of investment financing corresponds to "old view" models of payout taxation and the level of investment (Harberger, 1962, 1966; Feldstein, 1970; Poterba and Summers, 1985). This firm can raise $\$ 1$ at time 1 , produce $1+\pi$ at time 2 , of which $1+$ $\pi\left(1-\tau_{c}\right)$ remains after paying corporate taxes. The firm makes a dividend payment in the same amount. The cash flow to investors after payout tax becomes $1+\pi\left(1-\tau_{c}\right)\left(1-\tau_{p}\right)$. Alternatively, investors can make the alternative investment, receiving $r$. The firm should invest if:

$$
\pi\left(1-\tau_{c}\right)\left(1-\tau_{p}\right)>r .
$$

The firm without access to internal funding considers both corporate and payout-related taxes when deciding if it is optimal to invest. We can use equation (1) to derive an expression for the firm's cost of capital (which coincides with the cost of equity in this simple model without debt). If the required return is $r$, the cost of capital is:

$$
r^{E}=r \frac{1}{\left(1-\tau_{p}\right)}
$$

The minimum required return on the investment increases following an increase in payout taxes (recall that $r$ captures the risk of the project). As a result, investment of firms who issue equity to finance investment ("old view" firms) should decrease following an increase in payout taxes.

In the second case, we consider a firm with access to retained earnings. This assumption corresponds to the "new view" of payout taxation (Auerbach, 1979a; Bradford, 1981; King, 1977). The model predictions change when a firm has the ability to finance investment using internal funds. This firm makes a choice between paying out a $\$ 1$ (taxable) dividend in period 1 or investing in the project in order to return the after tax cash flow of $1+\pi\left(1-\tau_{c}\right)$ as a taxable dividend in period 2 . If the firm returns the $\$ 1$ in period 1 , investors receive $\left(1-\tau_{p}\right)$ which they can invest at return $r$. The firm should invest if:

$$
\left[1+\pi\left(1-\tau_{c}\right)\right]\left(1-\tau_{p}\right)>[1+r]\left(1-\tau_{p}\right)
$$

Note that payout in either alternative is completely subject to payout tax $\left(1-\tau_{p}\right)$. The investment condition therefore becomes:

$$
\pi\left(1-\tau_{c}\right)>r
$$

For firms with internal cash, the tax rate on payout is irrelevant to investment decisions (this is the standard new view result). The cost of capital for a firm that uses internal equity is:

$$
r^{I}=r
$$

${ }^{5}$ One concern about this assumption is that firms might finance marginal investment by debt if equity issues are taxed unfavorably and if debt and equity are (close) substitutes. Regarding the imperfect substitutability between debt and equity, see e.g. Myers (1977), Jensen and Meckling (1976). We discuss this issue more in our robustness section. 
In this case, the cost of capital is not affected by payout taxes and lower than for firms with external equity. This produces the standard new view result that the investment of firms that can fund all investment internally using retained earnings is unaffected by payout taxes.

This result may seem unrealistic. For example, a firm may be able to fund investment from profits today, but still consider external equity a possible source of funding tomorrow and thus relevant for the cost of capital and investment. Also, the above result is sensitive to the assumption that repurchases are taxable (e.g. requiring that the tax basis of shareholders be lower than the current stock price) and to general equilibrium effects ${ }^{6}$. We do not aim to test tax effects on aggregate investment of either old or new view firms. In fact, we are interested in the difference between the two types of firms. This follows directly from the two results for old view and new view firms: the after-tax cost of capital is lower for firms with inside equity. More formally, the derivative of $r^{I}-r^{E}$ with respect to payout taxes is positive. In other words, payout taxes create a wedge between the investment criteria (cost of capital) of the two types of firms. This yields the central conjecture we aim to test.

Hypothesis: The difference in investment between firms with that can fund investment internally using retained earnings ("new view firms") and those that need to raise external equity ("old view firms") is increasing in payout tax rates.

We refer to this prediction as the tax wedge theory. We believe this hypothesis is more robust to changes in the assumptions (see several examples below) than either of the inferences made for old and new view firms in isolation. We also believe it is of particular interest, since firms with and without internal funding ability are likely to vary systematically in terms of investment opportunities, so that a shift in the relative cost of capital, and the associated investment response, can be economically important. We next discuss several extensions, limitations and caveats of the model.

\subsection{Tax basis effects}

We developed this result assuming that payout is taxed. However, in many countries, investors can avoid some payout taxes, especially for payout in the form of repurchases (see Lewellen and Lewellen, 2006 as well as Rydqvist, Spizman and Strebulaev, 2010). Let us consider the case where not all capital gains are taxable. Assume that a firm can return cash through repurchases, that all shareholders are taxable investors, and that all shareholders have a tax basis, i.e. ratio of the tax basis of the shares (usually

\footnotetext{
${ }^{6}$ In a general equilibrium setting where aggregate investment is not fixed, but determined in equilibrium, the investment of new view firms will be indirectly affected by payout taxes that they do not pay. To see this, imagine that here are two firms in an economy, and that one reduces investment (the old view firm faces higher payout taxes and invests less). Then, the opportunities for investment in the other firm improves for one of three channels: through capital markets (the savings needs of households push up investment in new view firms, mediated through a lower $r$ ) or through product markets (retrenchment by some old view firms makes it easier for new view firms to make money, i.e. increases) or through labor markets (it becomes easier/cheaper to hire and increases).
} 
acquisition price) to the current value of shares, of $\beta(0 \leq \beta \leq 1) .^{7}$ Then, the effective tax rate on returns is $\tau_{\mathrm{p}}=\tau_{\mathrm{cg}} \beta$. The cost of capital for firms who finance marginal investments by internal equity is:

$$
\mathrm{r}^{\mathrm{I}}=\frac{\mathrm{r}}{\left(1-\beta \tau_{\mathrm{CG}}\right)}<\mathrm{r}^{\mathrm{E}}
$$

Intuitively, $\beta$ determines how much additional payout tax is triggered by a share repurchase or dividend payment. If $\beta$ is zero, there is no additional payout tax. As long as $\beta<1$, the result that internal equity is cheaper than external equity holds up. In other words, as long as payout is taxed, our result holds. Miller and Scholes (1978) argue that payout taxes can be avoided completely, and this would remove our predictions about relative investment and cost of capital. It is worth noting that the US treasury raises significant resources from both dividend taxes and capital gains taxes, suggesting that in practice, US investors at least are unable to avoid payout taxes.

In our empirical test, we use cash flow as a proxy for the firm's ability to finance investments using internal funds. Our model predicts that firms with high cash flow (who face $\mathrm{r}^{\mathrm{I}}$ ) are expected to be less sensitive to changes in payout taxes than firms with low cash flow (who face $\mathrm{r}^{\mathrm{E}}$ ), regardless of the exact tax basis, as long as there is some tax liability created by distributing cash to shareholders. However, the magnitude of the tax wedge will depend on the average tax basis, and we do take this into consideration in the robustness section.

\subsection{Financial investments (cash holdings)}

Our model could apply to physical investment as well as cash holdings. We can easily consider this inside the model. It is useful to first disregard payout taxes, i.e. consider a new view firm. Recall that equation (3) states that new view firms prefer payout to internal investment if $\pi\left(1-\tau_{c}\right)>r$ where $r=\widehat{r}\left(1-\tau_{i}\right)$ is the after-tax return for investors. Unlike most firm investment, cash investments can be done at largely similar terms by a firm's owners, even if they are small and dispersed. Thus, for cash, we might believe that the firm's return and investor's return coincide: $\pi=\hat{r}$ in which case equation (3) would suggest to keep cash outside of the firm. This implies that we can decide if cash holdings should be held inside the firm, from a tax point of view, based on whether $\hat{r}\left(1-\tau_{c}\right)>\hat{r}\left(1-\tau_{i}\right)$. In other words, if the return to cash is similar, taxes should determine the location of cash investment. This effect should combine with the effect of internal vs. external equity finance that we highlight in the basic model, so that we predict that low cash flow firms should hold more cash when payout-taxes are low.

To test this theory, we have to compare corporate income tax rates to taxation of personal income. We also need to correct for the possibility that corporations have better investment opportunities (i.e. at the same tax rate, it may be slightly better to hold cash inside the firm if it can get better returns, for

\footnotetext{
${ }^{7}$ If $\beta>1$, investors have a taxable loss. We rule this case out for simplicity.
} 
example through lower management fees). Finally, saving of cash is only observed for financially constrained firms (Almeida, Campello and Weisbach, 2004), so we need to condition on being constrained to have confidence in the prediction that payout taxes raises cash. We examine these predictions in Section 5.4 below.

\subsection{Agency problems}

Chetty and Saez (2010) present a model based on agency conflict between owners and managers, where payout taxes can affect investment in rich firms through shifting the CEO's choice between taxed payout and untaxed empire building (which involves over-investing). In this model, poorly governed rich firms may show perverse responses to taxes (i.e. higher investment when taxes are high). In this model, for well governed firms the relative investment of rich and poor firms is increasing in taxes (as above), and also for poorly governed firms (due to extra channel off shifting private benefit consumption). Thus, the predictions we test in this paper are consistent with this model as well (see Tables A.XIV to A.XVI in the Online Appendix). Although, to be precise, our findings do not necessarily support an empire building agency problem over other possibilities. See e.g. Malmendier and Tate (2005) for a different agency problem between investors and managers.

\subsection{Debt finance}

Several other factors can limit the relevance of the proposed effects of payout taxes. In particular, if firms face expensive equity, they may try to substitute by funding investment with debt. If debt is a good substitute for firms that need funding, the effect of taxes for required returns and investment decisions will be muted. Several factors could limit this: investing firms may not have suitable collateral for borrowing, may have already used up their debt capacity, or may be reluctant to increase leverage. We test the relevance for our results of potential substitution to debt financing in the robustness section below.

\section{Taxes on corporate payout across countries}

\subsection{Tax variation}

The prerequisite for a useful study of the relationship between payout tax policies and the allocation of investment across countries is a sufficient degree of identifying variation in dividend and capital gains tax regimes and tax rates both across countries and within countries across time. Tables 1 and 2, and Figures 1, 2, and 3 illustrate that this is the case for the 25 countries scrutinized in this study.

We count five major tax systems in our data set: classical corporate tax systems, shareholder relief systems, dividend tax exemption systems, and full and partial imputation systems. Classical corporate taxation systems (for example, currently used in Ireland, and previously in the Netherlands or Spain) are characterized by double taxation of corporate profits, that is, income, before it is distributed as dividends, 
is taxed at the corporate level, and later taxed again as dividend income at the individual shareholder level. This contrasts with shareholder relief systems (for example, currently used in the US, Japan, and Spain) which aim to reduce the full economic burden of double taxation that applies under a pure classical system. For example, at the individual shareholder level, reduced tax rates on dividends received or exclusion of a proportion of dividend income from taxation are common forms of shareholder tax relief. Under an imputation system (for example, used currently in Australia and Mexico, and previously in France), taxes paid by a corporation are considered as paid on behalf of its shareholders. As a result, shareholders are entitled to a credit (the "imputation credit") for taxes already paid at the corporate level. That is, shareholders are liable only for the difference between their marginal income tax rate and the imputation rate. Full and partial imputation systems are distinguished by the nature of the imputation credit, which may be the full corporate tax or only a fraction thereof. In dividend tax exemption systems (currently only Greece in our sample) dividend income is generally not taxed.

Table 1 shows that there have been many changes in payout tax systems over the last two decades. While in the first half of our sample period the classical corporate tax system dominates, from 2005 the shareholder relief system is the most widespread tax system. While there are only five shareholder relief systems in place in 1990, shareholder relief systems can be found in almost 70\% of the countries (17) in our sample at the end of the sample period. The reduction in the prevalence of full and partial imputation systems from 11 in 1990 to only 6 in 2008 is largely due to the harmonization of European tax laws that necessitated an abolition of differences in the availability of imputation credits for domestic and foreign investors across EU member states.

\subsection{Tax rates}

The significant trend from imputation systems and classical corporate tax systems to shareholder relief systems naturally coincides with the development of the absolute taxation of dividend income and capital gains. Yet, as Tables 1 and 2 illustrate, tax reforms are not necessarily accompanied by changes in the effective taxation of dividends and capital gains. Rather, much of the dynamics in dividend and capital gains taxation relate to pure rate changes. Changes occur frequently absent any tax system reforms.

In this study, we are interested in the effective tax burden on dividend income and capital gains faced by individual investors. One concern with our analysis is that the tax rates we measure do not have sufficiently close correspondence with actual share ownership of our sample firms. Rydqvist, Spizman and Strebulaev (2010) point to the reduced role of the taxable investors in recent decades. They suggest that the influence of private investors' taxes has likely been falling through time. In the extreme, if the marginal investor for every firm is a (tax neutral) institution, individual shareholder taxation should not matter. If this is true for our sample firms, we would find no effect. To the extent that we identify an 
effect of payout taxes, we can conclude taxable investors have some impact on firm prices (at least for a subset of firms). ${ }^{8}$

Similarly, the increasing role of cross-country stock holdings might affect our ability to isolate true tax rates faced on payout by equity owners through the tax rules for domestic investors. Our data do not allow us to identify the fraction of foreign ownership in a company. However, since there is strong evidence of a substantial home bias in national investment portfolios (see, for example, French and Poterba, 1991; Mondria and $\mathrm{Wu}, 2010$ ), we believe domestic tax rules are likely the most important source of time series variation in tax rates. The tax rates applicable to domestic investors is the most plausible approximation for the typical investor's tax burden, especially for smaller firms, where international ownership is likely lower.

The first, immediate, observation from Table 2 is that the level of taxation on dividends and share repurchases varies considerably across countries and time. Tax reforms per se are not necessarily accompanied by changes in the effective rate of taxation of dividends and capital gains. As we report in Panel A of Table 2, the highest average tax rates on dividend income over the sample period can be observed in the Netherlands, Denmark, Switzerland, France, and Ireland. Peak values range from 66.2\% in Sweden (1990), to $60.9 \%$ in Denmark (1990), to $60.0 \%$ in the Netherlands (1990-2000), to $47.3 \%$ in Korea (1990-1993), to 46\% in Spain (1990/1991, 1993/1994). Over the same period investors faced the lowest average tax burden in Greece - a dividend tax exemption country and the only mandatory dividend country in our sample - and in Mexico, Finland, New Zealand, and Norway. The within-country standard deviation ranges from $10.8 \%$ to $20.5 \%$, and the within-country differences between maximum and minimum tax rates from $25 \%$ to $38 \%$, for Norway, Sweden, the Netherlands, Japan, the US and Finland, which provide the most variation in dividend tax rates over the sample period (Table 3, Panel A, and Figure 1). In contrast, we observe the most stable tax treatment of dividends in Greece, Mexico, Austria, Poland, and Portugal, where the personal income tax rate fluctuates within a narrow band of at most 5 percentage points difference between peak and lowest taxation over the sample period. On average, the difference between maximum and minimum dividend tax rate in our sample countries in 1990-2008 is $19.9 \%$, thus underpinning the substantial time-variant differences in dividend tax rates.

Capital gains taxation across countries is special in many respects and often strongly intertwined with the legal treatment of share repurchases. For example, in some European countries share repurchases were either difficult to implement (for example, France) or illegal (for example, Germany and Sweden) until

${ }^{8}$ The Rydqvist et al prediction seems to be borne out in US dividend policy: Chetty and Saez (2005) and Perez-Gonzalez (2003) show that firms with a large share of institutional (tax exempt) ownership exhibit smaller changes in policy after the 2003 tax cut. For our sample, which contains many non-US firms, tax exempt investors may be a smaller factor. Unfortunately, we lack the requisite ownership data to test whether there is a similar pattern in our sample. 
the turn of the 3rd millennium (Rau and Vermaelen, 2002; DeRidder, 2009). Moreover, in some countries with high taxes on dividends and low capital gains taxes (such as in Belgium, in the Netherlands before 2001, and in Switzerland since 1998), specific tax provisions existed to discourage share repurchases. In Japan, restrictions on corporate share repurchases thwarted corporations from buying back their own shares until enactment of a special law in 1995. Since the mid-1990s, the Japanese government has gradually relaxed and removed restrictions on share repurchases, originally as a part of emergency economic measures to revitalize the economy and its tumbling stock market (Hashimoto, 1998). In Panel B of Table 2 we report capital gains tax rates across our sample countries that take these effects into consideration. The tax rates are applicable to investors with non-substantial shareholdings and holding periods that qualify as long-term investments in accordance with country-specific tax legislation. We show that over the sample period, on average, the most unfavorable tax environment for capital gains prevailed in Denmark, the UK, Australia, the Netherlands, and Canada, while in eight countries capital gains are generally tax exempt. We observe peak capital gains tax rates in the Netherlands (1990-2000), Australia (1990-1999), Poland (1994-1996), and Switzerland (1998-2007). The range of capital gains tax rates is substantial - from $0.0 \%$ to $60.0 \%$. With standard deviation greater than $14.5 \%$ and differences between maximum and minimum tax rate of $31 \%$ to $60 \%$, the Netherlands, Switzerland, Belgium, and Poland exhibit the largest within-country variation in capital gains tax rates across countries (Table 2, Panel B, and Figure 2). In contrast, capital gains taxation is constant in 1990-2008 in Austria, Germany, Greece, Korea, Mexico, New Zealand, and Portugal. On average, the within-country difference between maximum and minimum capital gains tax rate in our sample countries in 1990-2008 is $18.7 \%$, thus providing further ample identifying variation in corporate payout taxation.

\subsection{The potential endogeneity of tax changes}

Our identification (both for non-parametric and parametric tests) relies on the assumption that no event apart from the tax changes we study generates differential investment for firms with and without access to internal investment funding and changes at the same time as taxes. We are particularly concerned with some omitted macro-economic variable that affects the relative investment opportunities of these groups of firms.

In general, it is our sense that many factors affect the politics of payout taxes. Many of these factors appear unrelated to corporate investment and performance. For example, the US tax cuts were motivated by the political philosophy of the administration. The 2000/2001 German Tax Reform Act formed part of a series of European Union harmonization initiatives across member states and was the first major tax reform in Germany since 1977. The German Tax Act changed the previous imputation system, which restricted the free movement of capital within Europe, and introduced an internationally more compatible shareholder relief system. It was not designed to affect relative investment of low cash and high cash 
firms. Of course, these are just two examples. In Section 6 below, we show that tax changes neither precede nor follow changes in key macro-economic variables on average. This provides some support for the notion that tax changes are not made due to some factor that also changes the relative investment of rich and poor firms. In the online appendix (Table A.I), we also show that, for example, the nonparametric results for the German reform highlighted above are very similar to our baseline results for the full sample.

\section{Data sample}

\subsection{Firm data}

We source our firm-level data from the July 2009 edition of the WorldScope database and restrict our analysis to those countries for which conclusive tax data for the full sample period could be obtained. To ensure a meaningful basis for the calculation of our country-level statistics we also exclude from our sample firms from countries for which we have less than 10 observations after the below sample adjustments. The start year of our analysis is 1990 for two reasons. First, WorldScope provides less than comprehensive coverage of individual data items for non-U.S. firms before 1990. An earlier start may thus have biased our results for earlier sub-periods away from international evidence towards evidence from North America. Second, 1990 is a historically logical year to begin. With the transformation into capitalist, democratic systems in 1990, many former communist countries have only begun to incorporate dividends and capital gains taxation in their tax laws. We use data through 2008. We collect data on active as well as dead and suspended listings that fulfill our data requirements to avoid survivorship bias.

Table 3 Panel A summarizes the composition of our sample. Financial and utility firms have motives to pay out cash that are different from non-financial firms (see e.g., Dittmar, 2000 and Fama and French, 2001). We therefore restrict our sample to non-financial and also non-utility firms, defined as firms with SIC codes outside the intervals of 4,900-4,949 and 6,000-6,999. We also exclude firms without an SIC code. We further restrict our sample to firms with non-missing values for dividends to common and preferred shareholders, net income, sales, and total assets for at least 4 consecutive years in the 1988-2008 period. From the original set of firms, we eliminate observations with negative or missing stock price, dividends, or share repurchase information, firms whose dividends exceed sales, and firms with an average weekly capital gain of over $1,000 \%$ in one year. To prevent extreme values and outliers from distorting our results we further eliminate observations of our dependent and independent variables that are not within the 1st and the 99th percentile of observations, and we also drop firm observations with total assets less than USD 10 million (see Baker, Stein, and Wurgler, 2003). ${ }^{9}$ This returns our basic

\footnotetext{
${ }^{9}$ We obtain very similar results when winsorizing variables at different levels. Table A.II in the Appendix presents regression results from samples which we winsorize at the $5 \%$ and the $2 \%$ level.
} 
sample of 7,661 companies (81,222 firm-year observations) from 25 countries. We obtain annual personal income tax on dividends, and capital gains tax data for the 25 countries in our sample from Jacob and Jacob (2011). This comprehensive tax data set allows a heretofore unavailable, thorough analysis of payout taxes and the allocation of investment within a multi-country, multi-year framework.

\subsection{Investment variables}

Table 3 Panel B presents summary statistics for our investment variables. Our proxies for firm investment are threefold. First, we create the variable Investment, defined as additions to fixed assets other than those associated with acquisitions (capital expenditure, including additions to property, plant and equipment, and investments in machinery and equipment) normalized by total assets. Second, we include PPE Growth, the growth in plant, property, and equipment from $t-1$ to $t$ divided by the end-ofyear $t-1$ assets. Our final measure of investment intensity is Asset Growth, the ratio of growth in total assets normalized by total assets of the firm. The numerator in our investment variables is measured one year after our total assets variable, the denominator. Before computing investment, we translate capital expenditures, PPE, and total assets in US dollars into real terms (base year 2000) by using the US GNP deflator (World Development Indicators, Worldbank 2010). In our sample, firms on average have capital expenditures amounting to $5.9 \%$ of the value of their prior year total assets. The average growth rate in plant, property, and equipment is $8.1 \%$ and the average growth rate in total assets of $7.9 \%$. The range of values of investment is considerable - from $0.8 \%\left(10^{\text {th }}\right.$ percentile) to $12.7 \%$ ( $90^{\text {th }}$ percentile) (Investment), $-13.8 \%$ to $29.0 \%$ (PPE Growth), or $-17.0 \%$ to $30.8 \%$ (Asset Growth).

\subsection{Tax variables}

Summary statistics for tax variables and controls are presented in Panel C of Table 3. All tax rates that we employ apply to investors with non-substantial shareholdings and holding periods that qualify as long-term investments in accordance with country-specific tax legislation. We construct three tax variables.

Dividend Tax is the personal income tax rate on dividends in a country and year (in \%). Imputation credits and country-specific tax exemptions available to investors have been taken into account when calculating this "effective" rate. For example, as per the definition of imputation systems, if the tax rate on dividend income is $50 \%$ and the available imputation credit is $20 \%$ then the 'effective' rate we employ is $30 \%$. If, as for example in Germany from 2001-2008, $50 \%$ of dividend income is tax exempt, then the effective rate is half the statutory tax rate. Its range of values is wide, from $0 \%$ to $66.2 \%$ with mean dividend tax burden of $27.8 \%$ and standard deviation of $12.6 \%$, reflecting the considerable variation of payout taxes across countries and over time. Effective $\operatorname{Tax} C$ is the country-specific weighted effective corporate payout tax rate (in \%). It is calculated by weighting the effective tax rate on dividends and share 
repurchases by the importance of dividends and share repurchases as payout channels in a country over the 1990-2008 period. With this measure, we follow prior analyses of effective capital gains taxation and assume the effective tax rate on capital gains from share repurchases to be one-fourth of the statutory tax rate (see La Porta, Lopez-de-Silanes, Shleifer, and Vishny, 2000 and Poterba, 1987). This way, we control for the effect that capital gains are taxed only at realization and that thus effective capital gains tax rate may be significantly lower than the statutory rate. ${ }^{10}$ The importance weight of dividends in a country is calculated by averaging the dividend-to-assets ratio across firms and years, and then dividing by the average total payout ratio (sum of dividends and share repurchases normalized by total assets) across firms and years. The share repurchase weight is calculated analogously. ${ }^{11}$ Average Tax $C$, the country weighted average tax, is an alternative measure of the average corporate payout tax rate (in \%). It is obtained by weighing each year's dividend and statutory capital gains tax rate by the relative importance of dividends and share repurchases as payout channels in a country over the sample period. ${ }^{12}$

In principle, there are reasons to prefer either of the measures. The dividend tax rate disregards the tax burden of repurchases, but requires no assumptions about the capital gains taxes incurred when firms retain earnings (i.e. retaining earnings makes the share price higher, thereby increasing current capital gains sellers of share, reducing future capital gains taxes for buyers). We have also rerun all our regressions with a weighted average of tax rates where we allowed weights to vary not only by country but also by year (i.e. there is one set of weights for each country-year, which is applied to tax rates that also may vary by country-year). The country-average tax rate may be unrepresentative if the mix of payout varies a lot, but raises fewer endogeneity concerns. In practice, country average tax rates and country-year average tax rates are very similar, and the regression results are very close, so we do not report results for the latter. The mean values of our Effective Tax $C$ and Average Tax $C$ variables are $18.3 \%$ and $24.5 \%$, with standard deviations $9.1 \%$ and $10.3 \%$. Figure 3 illustrates the inverse cumulative distribution function (CDF) of tax rates across observations in our sample. As is evident, the variation in tax rates is considerable by any of our three tax measures, reflecting the substantial tax experimentation taking place during our sample period. Because of the uneven number of firms across countries, longlived tax systems in large countries (the US and Japan) produce lots of data.

\footnotetext{
${ }^{10}$ The assumption that the true tax rate is a quarter of the stated rate is not important to our conclusions. We get very similar magnitudes using other assumptions (including anything in the $[0,1]$ range).

${ }^{11}$ Throughout we use cash dividends only, to avoid that differences in the tax treatment of cash and stock dividends infect our results. Our share repurchase variable is measured by the actual funds used to retire or redeem common or preferred stock and comes from the cash flow statement.

${ }^{12}$ Weighing the capital gains tax by the prevalence of repurchases has the important advantage of automatically dealing with limitations on repurchases. If a country has high taxes on dividends and low taxes on repurchases, but severely restricts repurchases through laws and regulations, it is not fair to say that payout faces low taxes. Because we weight by actual quantities, we will put a small weight on the low payout tax rate.
} 


\subsection{Other variables}

Our firm-level variables measure internal funds, capital structure, Tobin's q, and growth. The availability of internal funds for investment is measured with three alternative variables: a) Cash Flow is the funds from operations of the company measured as the ratio of cash flow relative to total assets, $b$ ) Cash is defined cash holdings over total assets, and c) EBITDA measures earnings before interest, tax, and depreciation as a fraction of total assets. Unlike cash flow, EBITDA does not include tax payments, or increases in working capital.

We measure capital structure through leverage, defined as total book debt over total book assets. We include Tobin's q, the ratio between the market value of equity plus the book value of debt to the replacement (book) value of the assets $(Q)$. This variable can measure future profitability, that is, the quality of investment opportunities, as well as measurement error arising from accounting discrepancies between book capital and economic replacement costs. We include the natural logarithm of growth in sales from year $t-2$ to $t$ (Sales Growth) and the relative size of a firm (Size) to control for the fact that smaller, high growth firms have greater profitable investment opportunities than bigger and more mature companies. We measure the relative size of a firm as the percentage of sample firms smaller than the firm for each country in each year. The numerator in our firm-level controls is measured one year after our total assets variable, the denominator.

\section{Tests and results}

\subsection{Internal resources and investment under different taxes: non-parametric results}

The simplest way of testing how payout taxes impact investment of firms with and without access to internal equity is to track firm investment around tax reforms. We do this in our panel sample by sorting firms in each country-year into quintiles based on the ratio of cash flow to assets. This is meant to capture firms' ability to finance investment internally. We then calculate average investment over assets for each group in each country-year cell. We demean these ratios by country-year, to account for cross-country and time variation in average investment levels. Next we identify tax changes, using the country-weighted average payout tax rate (Average Tax $C$, results are similar with the two alternative measures). We focus on events where payout taxes changed by at least three percentage points. We exclude any events with fewer than thirty observations (firms) in the first year of the tax change. To avoid overlapping periods, and following Korinek and Stiglitz (2009), we further exclude events where a substantial tax cut (increase) is followed by a tax increase (cut) within two years following the original reform (Sweden 1994/1995, Australia 2000/2001, Norway 2001/2002, and Korea 1999/2001). As Korinek and Stiglitz show, where firms perceive tax changes as only temporary, tax changes may generate smaller effects. Since tax reforms are often debated extensively, it seems possible that these tax reversals can be predicted 
by some firms and investors. We further exclude an event where the effects of the payout tax change overlap with a substantial corporate tax reform (Korea 1994). The remaining 29 events include 15 events with an average tax drop of 9.8 percentage points (median 5.5) and 14 events with an average tax increase of 8.4 percentage points (median 5.6).

For every event, we track the average ratio of investment to lagged assets for firms in each quintile in the three years leading up to the tax change, the first year when the new rules apply, and the two years following the tax change. Average differences in investment between high and low cash flow firms around the tax events are shown in Figure 4. This graph shows the difference between the average investment of the low and high cash flow quintiles. The point estimate is positive in all years, i.e. the firms with high internal cash flows tend to invest more. There is no apparent trend in the investment rate difference prior to a tax reform. After a tax reform, however, the investment difference follows the direction of the tax change (e.g. the difference increases when taxes are raised and falls when taxes are reduced).

In Table 4, we provide a detailed analysis of the relative investment of high and low cash flow firms. The table shows average investment (demeaned by country year) for both pre- and post-reform periods, and for the two groups of firms. The difference and difference-in-difference estimates are shown as well. The time period analyzed around tax events is from five years before to two years after the reform. The effects are in line with the hypothesis that higher taxes should be associated with relatively higher investment in those firms that have access to internal cash (Column 3, Panels A and B). After payout tax increases (decreases) the importance of the availability of internal resources for high investment increases (decreases) significantly. On average, the difference in investment between low and high cash flow firms increases from $5.33 \%$ to $7.59 \%$ following a payout tax increase. When payout taxes are cut, the difference in investment falls from $7.27 \%$ to $5.54 \%$. These results are consistent with the prediction that corporate payout taxes drive a wedge between the cost of inside and outside equity and that high such taxes favor investment by firms with internal resources.

We also use a matching procedure to obtain samples of firms that are similar across the variables sales growth, Tobin's q, leverage and size but that differ in cash flow. This addresses concerns that our non-parametric results are driven by other covariates that we do not control for in the OLS regressions. In Table A.III of the Appendix, we replicate results from Table 4 using a propensity score matching procedure and only include firms where the predicted score is above 0.5. Our results using the matched sample are very similar to our baseline results.

The tax-based theory of the cost of capital wedge suggests that firms with inside funding should not respond to tax incentives (they are "new view" firms). Nevertheless, there is movement in the high cash flow group of firms in Table 4 (after a tax increase, they increase investment relative to the median firm), 
disagreeing with this prediction. There are at least five possible explanations for the investment changes made for high cash flow firms. First, countercyclical fiscal policy could generate patterns in aggregate investment consistent with Table 4. In principle, forces of political economy could produce endogeneity in either direction: tax increases may be more likely in contractions when the government budget is in deficit or in expansions when there is less political pressure to stimulate the economy with fiscal expansion. Investment tends to fall after tax reductions and rise after tax increases, which might be due to countercyclical tax policy (i.e. taxes are raised at times when investment is temporarily low and can be expected to increase). This type of endogeneity is a key motivator for our approach of using difference-indifference tests with demeaned investment. By looking at relative cross-firm differences in investment within a country and year, we difference out aggregate level effects. ${ }^{13}$ A second possibility is that agency problems are a driver of investment in our sample firms in a way consistent with Chetty and Saez (2010): when tax rates go up, pressure to pay out cash is reduced, permitting managers to undertake excessive investment. Unlike the new view, this theory predicts that cash rich firms will respond to tax changes, and that aggregate investment may respond perversely to payout taxes. Third, cash rich firms may experience increased investment opportunities when cash poor firms withdraw. Fourth, the aggregate patterns may be related to the permanence of tax changes. Korinek and Stiglitz (2009) predict that a tax cut which is expected (by firms) to be temporary can lead to inter-temporal tax arbitrage: firms want to take advantage of the temporarily low tax by paying out more cash, and do so in part by reducing investment. This tax arbitrage is done by mature (i.e. cash rich) firms who generate the bulk of payout. Fifth, general equilibrium effects may link the amount of investment in different parts of the economy (see Section 2 above). Thus, there are at least five reasons that the investment of cash rich firms is correlated with tax changes in the direction evident in Table 4. Importantly, under all five scenarios, our inferences based on the relative investment of high and low cash flow firms remains valid, i.e. the difference-in-difference result tells us that low payout taxes favors cash poor firms in a relative sense. We believe the lessons learned from the cross-sectional differences are unambiguous and of great potential importance for understanding corporate investment and for setting public policy.

The estimated difference-in-difference estimate varies considerably across events. Figure 5 plots the empirical densities of difference-in-difference estimates for tax decrease and increase events. Two (three)

${ }^{13}$ We expect that endogeneity between payout tax changes and the dispersion of investment (as opposed to the level) is much less likely to be important. The correlation table in Appendix A.IV supports this expectation. It also highlights that tax changes are at best weakly related to other macroeconomic determinants that affect the level of investment in an economy. Tax changes are only weakly correlated with current and prior year GDP growth and not significantly related to other macroeconomic variables with the potential to influence investment: inflation, and cost for setting up businesses (see e.g., Djankov, Ganser, McLiesh, Ramalho, and Shleifer, 2010), and government spending measured by subsidies, military expenditures and R\&D expenditures. We also implement several robustness tests to control for government policy in various ways (see Section 5). 
of the 15 (14) tax decreases (increases) have difference-in-difference effects that are in conflict with our hypothesis. On the contrary, one third of the tax decreases reduce the difference in the ratio of investment to assets between high and low cash flow firms by more than 2.5 percentage points - more than one third of the pre-tax change differences. $40 \%$ of the tax raises increased the wedge in investment between high and low cash flow firms by more than 2.5 percentage points, i.e. more than $50 \%$ of the pre-tax change differences.

\subsection{Internal resources and investment under different taxes: OLS results}

Compared to the non-parametric tests, the regressions have several advantages. They use more of the variation in the data, and can easily integrate both tax increases and decreases in the same specifications. They also allow for more detailed controls of firm heterogeneity. However, it is harder to study the detailed time patterns in the regression tests. By construction, regressions put more weight on those events that happen in countries with many firms (i.e., Japan and the US), ${ }^{14}$ although in principle that can be changed by using GLS (we do not do this, although we always cluster errors by country-year, so that we properly take into account the amount of statistical power we have). ${ }^{15}$ The regressions exploit all of the variation in tax rates that is visible in Figure 3.

For our baseline tests, we regress investment on firm controls, fixed effects for firms and for countryyear cells, and the interaction of the payout tax rate with cash flow (we do not include the level of the tax, since this is absorbed by the country-year fixed effects). ${ }^{16}$ We control for relative size, Tobin's q, cash flow, and leverage. We include firm and country-year fixed effects in all our regressions. These help control for business cycles and other macro-economic factors. The main variable of interest is the interaction of internal resources (cash flow) and taxes. If taxes raise the relative cost of external equity, we expect high taxes to coincide with a stronger effect of cash flow on investment (since high cash flow means a firm can finance more investment with cheap internal equity). We therefore predict that the interaction coefficient should be positive. Regression results are reported in Table 5, for each of the three

${ }^{14}$ We get similar results when excluding Japanese and U.S. firms (Table A.V of the Appendix).

${ }^{15} \mathrm{We}$ also test the robustness of our results to regression specifications in which we cluster standard errors at the country level and at the country-industry level. Standard errors for the cash flow*tax interactions obtained from these additional specifications are very similar to those in our baseline tests. They are reported in Table A.VI of the Appendix.

${ }^{16}$ For brevity, in what follows we only discuss the results obtained by using our Investment dependent variable. The results using our alternative measures of investment, PPE Growth and Asset Growth, align very closely with the results reported in this section. The results are displayed in Table A.VII of the Appendix. We also ensure robustness of our results to alternative ways of scaling our measures of investment. In what follows, we use book assets to scale investment. As our sample includes smaller and nonmanufacturing firms with modest fixed assets and varying degrees of intangible assets this appeared the logical approach (cf. Baker, Stein, and Wurgler, 2003). Nevertheless, following Fazzari, Hubbard, and Petersen (1988) and Kaplan and Zingales (1997) we also investigate robustness of our results to using the alternative denominators property, plant, and equipment (PPE) and the book value of fixed assets to scale investment. The estimated coefficients for the tax-cash flow interaction variable are again consistently positive and significant when we use these alternative scale variables for investment. 
tax variables. The estimated coefficient for the tax-equity interaction variable is consistently positive and significant. In other words, the higher payout taxes are, the stronger is the tendency for investment to occur where retained earnings are high. As predicted by the tax wedge theory, payout taxes "lock in" investment in firms generating earnings and cash flow. The estimated magnitudes are large. For example, going from the $25^{\text {th }}$ percentile of the country-weighted average tax rate $(15.0 \%)$ to the $75^{\text {th }}$ percentile (32.2\%) implies that the effective coefficient on cash flow increases by 0.029 , an increase by $32.8 \%$ over the conditional estimate at the $25^{\text {th }}$ percentile. Using the country-weighted effective tax rate, the effect is slightly larger. Going from the $25^{\text {th }}$ percentile $(7.8 \%)$ to the $75^{\text {th }}$ percentile $(25.2 \%)$ implies that the effective coefficient on cash flow increases by $0.037,36.6 \%$ more than the baseline estimate in Table 5 . One implication of this is that the positive cash flow coefficient in investment regressions (Rauh 2006) may in part reflect the higher cost of capital for firms without access to internal funds (the literature has mainly focused on financial constraints and varying investment opportunities as explanations of such coefficients).

The high R-squared in the regressions in Table 5 stems largely from the many firm fixed effects included. On their own, these explain about $52 \%$ of the variation in investment rates. This suggests that they may be important to include, and we maintain them in all regressions. In fact, their inclusion does not change our estimates for the tax-cash flow interaction noticeably.

We next use alternative measures of internal equity to check the robustness of our results thus far. We use the ratio of EBITDA to lagged assets as an alternative flow measure, and cash to lagged assets as a stock measure. Conceptually, a stock measure may be more natural than a flow measure, but cash may be financed on the margin by debt, in which case this becomes less informative about whether the firm has internal equity. In Table 6 , both measures are interacted with all three tax variables. Of the six coefficient estimates, five are significantly different from zero. The magnitudes are smaller than those reported for cash flow in Table 5. We have also used further measures of internal resources, such as net income, or operating income. Results are similar (Table A.VIII of the Appendix).

In a next step, we consider more flexible econometric specifications. Thanks to the panel structure of the data set, we can allow the coefficient on cash flow to vary across countries and years, in essence replicating the identification strategy of the many studies exploiting the 2003 tax cut in the US (for seventy nine changes across 25 countries). In Table 7 we report regressions including interactions of cash flow with both country and year indicator variables. Allowing the slope on cash flow to vary by country, we can rule out any time-invariant differences in the relation between payout taxes and the allocation of investment in different countries. For example, accounting differences could make cash flow less precisely measured (reported) in some countries, where we would therefore see a smaller slope on cash flow due to attenuation bias. As long as such issues are time-invariant, we can eliminate any effect on our 
results by including the interaction of country fixed effects with cash flow. The coefficient estimates for the cash flow-payout tax interaction remain statistically significant, and are somewhat large across the board (the firm controls have coefficients that are very similar to base line specifications). In fact, allowing these extra controls the estimated magnitudes are larger than those estimated in Table 5. The effective coefficient on the cash flow*tax interaction increases by 0.0002 (dividend tax), 0.0006 (Effective Tax C), and 0.0004 (Average Tax C) when compared to the coefficients reported in Table 4. The R-squared increases by about twenty-five basis points. Thus, a more conservative estimation technique gives a more precise result in line with the predictions of the tax wedge theory. In Table A.IX of the Appendix we extend our analysis of the more demanding flexible specifications by using cash flow percentile ranks rather than the raw cash flow measure. This serves as an additional check that our results are not driven by the extremes of the distribution of cash flow. Coefficient estimates on our cash flow * tax interactions are much more significant than those for the raw CF variables.

An auxiliary prediction of the theory of tax-induced cost differences between internal and external equity is that high taxes reduce the need to reallocate resources from profitable to unprofitable firms. Therefore, high taxes should reduce the amount of equity issues. ${ }^{17}$ This provides an additional falsification test. We test this by using firm-level data on payout tax and quantities of equity raised. If we cannot see a negative correspondence between payout tax and amount of equity issues, it becomes less plausible that our tax measure properly captures variation in the cost of equity. Table 8 presents tests of the predicted negative relation between taxes and equity issues in our sample. To help control for market timing (as opposed to payout tax timing), we control for recent stock return in the equity issues regressions. As predicted, the coefficient estimate is negative for all three measures of taxes. A ten percentage point increase in the dividend tax rate (the country average payout tax rate) predicts a drop in equity issuance by $9 \%$ (12\%) of the unconditional mean. High payout taxes are associated with both low investment and low equity issuance among firms with low profits. This is consistent with taxes as a driver of the cost of capital. It also suggests one channel through which the differential investment responses to taxes come about: with lower taxes, domestic stock markets reallocate capital to firms without access to internal cash.

\subsection{Difference-in-difference analysis: old view firms vs. new view firms}

We next sort firms by their likely access to the equity market. This is an important distinguishing feature between new view and old view models. According to the new view, all firms finance internally

17 The same prediction applies to payout: lower taxes should be associated with more payout. However, this prediction is less unique. If firms perceive tax changes as predictable, they may attempt to time payout to times when taxes are low (e.g., Korinek and Stiglitz, 2009). It therefore seems that testing equity issues provides better discrimination among theories than testing payout volumes. 
(on the margin), and therefore do not respond to taxes on payout. According to the old view, all firms finance their investment externally (again, on the margin), and therefore respond to taxes on payout (their cost of capital increases in such taxes). We hypothesize that the two assumptions fit different firms. By sorting firms by access to the equity market, we may be able to test the two theories. We attempt to sort firms into those that can source funds in the equity markets (old view) and firms that have to rely more on internal resources to finance investment (new view). To classify firms, we use three methods: predicted equity issues, actual equity issues in preceding years, and the Hadlock and Pierce (2010) index of financial constraints. We cannot condition on payout to distinguish financially constrained vs. unconstrained firms, since payout may be determined simultaneously with investment (the dependent variable).

We estimate the effect of taxation on the cash flow sensitivity of investment separately for two the groups of firms. In Table 9, Panel A, we sort firms based on the predicted probability that a firm issues shares using common share free float, share turnover, sales growth, leverage, market capitalization and market-to-book. We define firms as old view firms if predicted equity sales are above $2 \%$ of lagged assets. In Panel B, we define firms as old view firms if the sum of the net proceeds from the sale/issue of common and preferred stock over the preceding year exceeded zero, and as new view firms otherwise. In Panel C, we follow Hadlock and Pierce (2010) and classify firms as new view if the firm is within the two lowest quintiles of age and size distribution in one country-year. For all three classifications, there is a sizable difference in the effect of taxation on the marginal source of funds for investment between old view firms and new view firms. The differences between the coefficients are statistically significant at the $5 \%$ level or better in each pair of regressions. Our results are robust to alternative measures of financial constraints. For example, in Table A.X of the Appendix, we classify firms based on the KZ index (Kaplan and Zingales, 1997). For old view firms, the cash flow coefficient is always sensitive to tax rates, as predicted. For new view firms, the coefficient estimate is positive but smaller and insignificant in all cases. $^{18}$

\subsection{Financial investments (cash holdings)}

So far - given the definition of our dependent variables - our tax wedge theory predictions have shown to hold for investments in the production technology of the firm. If certain pre-conditions are met, it is natural to expect that the implications of the tax wedge theory are not that different for cash investments. For example, there could be a difference in returns or tax rates between corporations and owners. In this case, corporate cash holdings could be desirable if corporations can get after-tax higher

${ }^{18}$ The results in Table 9 are robust to using the dividend tax rate and the country-weighted effective tax rate instead of the country-weighted average tax rate for this analysis (Tables A.XI and A.XII of the Appendix). 
return than owners. Therefore, lower payout taxes may allow external equity-dependent firms to increase their cash investment just as physical investment. To be specific, for cash-constrained firms, an increase in payout taxes should shift cash investments towards firms with high cash flow.

We test the model's implications for cash investments empirically. To do so, and in line with previous literature (see, for example, Almeida, Campello and Weisbach, 2004 on cash flow sensitivities of cash), we first isolate those firms that are financially constrained. We identify financially constrained firms by the Hadlock and Pierce (2010) index. As, Almeida, Campello and Weisbach (2004), in the absence of financial constraints we expect no systematic patterns in cash policies because changes in cash holdings for unconstrained firms should depend neither on current cash flows nor on future investment opportunities. We further focus on country-years with high probability that corporations can get after-tax higher return than owners. This is the prerequisite for holding cash inside the firm to be more tax efficient than distributing it to shareholders. We focus on tax rate differentials - by comparing corporate tax rates to taxation of interest income of private individuals. To do so, we first collect OECD (Organisation for Economic Co-Operation and Development) (2012) data on statutory tax rates for personal income. We then identify country-years where the top personal income tax rate exceeds the corporate income tax by at least 3\%, generating - all else equal - a non-trivial tax advantage to keeping cash inside the firm for tax reasons. To further avoid potentially confounding effects from the strong interrelationship between corporate tax and income tax in full imputation systems we focus only on observations from countryyears with non-imputation systems.

Table 10 presents linear regression results for cash holdings, estimated over the 1990-2008 period. We find, as predicted, that for financially constrained firms in corporate tax advantaged country-years, cash investment is statistically significantly affected by payout taxes as predicted and shown earlier for physical investment. Specifically, for financially-constrained (external equity-dependent) firms an increase in payout taxes shifts cash investments towards firms with high cash flow. The estimated magnitudes of these effects are large and even greater than the earlier results seen for physical investment. For example, going from the 25 th percentile of the country-weighted effective tax rate $(7.8 \%)$ to the 75 th percentile (25.2\%) implies that the effective coefficient on cash flow increases by 0.1235 , an increase by $65.5 \%$ over the conditional estimate at the 25 th percentile. As predicted, these effects cannot be observed for non-financially-constrained firms.

\section{Robustness tests}

We next turn to several important additional robustness tests. One concern about our results is that tax changes are associated with other policy changes, which change firms' investment behavior. After all, governments are unlikely to set their tax policies completely independently of other developments in an economy. In particular, our regressions and non-parametric tests might be biased if tax changes were 
motivated by factors related to the relative investment of cash-rich and -poor firms. If, for example, taxation, cash flow and investment all change simultaneously in response to other macroeconomic determinants or government policies then we need to be concerned about endogeneity. Throughout our analyses we have used a number of checks to ensure robustness of our results to endogeneity concerns. For example, in our non-parametric test we have relied on differences in investment across firms instead of investment levels. Similarly, in all regressions we include country-year dummies to ensure that average investment is taken out (and, likewise, any particular government investment initiative that may inflate investment in a given year). Nevertheless we turn to several important additional robustness checks below. They address concerns that tax rates change in response to policy variables or macroeconomic determinants that might also affect the allocation of investment across firms (thus causing false positive conclusions about taxation).

\subsection{Tax systems}

We now consider further features of the tax system. We first want to control for the corporate tax rate. Corporate taxes may be connected to payout taxes for many reasons, including government budget tradeoffs, and political preferences (i.e. pro-business). Corporate taxes might also affect how important internal resources are for firms. ${ }^{19}$ Therefore, if different features of the tax code are correlated, an empirical link between payout taxes and relative investment across firms might be reflective of a true relationship between corporate taxes and relative investment. To make sure our results are not biased in either direction we include the interaction of corporate tax with firm cash flows. Here, we need to make a distinction between imputation system and other tax regimes. In imputation systems, corporate and payout taxes are particularly strongly intertwined as corporate tax at the firm level is "pre-paid" on behalf of shareholders and can be credited against payout taxes at the individual shareholder level. Thus, the corporate tax rate is in some way a measure of investor taxes.

To distinguish tax systems we thus also add an interaction of cash flow*corporate tax with the dummy variable Imp, which takes the value of 1 for imputation systems, and zero otherwise. The results are reported in Table 11. The interaction of corporate tax with cash flow is insignificant in all specifications, suggesting that outside of imputation systems, the corporate tax rate is not related to our findings. The triple interaction with the imputation system dummy is positive and significant, suggesting that in imputation systems, internal cash flow is a stronger predictor of investment when taxes are high. In other words, internal resources appear to matter more when corporate taxes are high. One interpretation of this coefficient is that when taxes are high, financial constraints bind more than at other times (see e.g.

\footnotetext{
${ }^{19}$ For example, if many firms are financially constrained, they may be unable to respond to lower corporate tax rates by investing more. In that case, lower tax rates may coincide with lower coefficients on internal resources.
} 
Rauh 2006). Importantly for our purposes, the interaction of cash flow and payout tax is not much affected. The coefficient estimates remain significant (although the significance is somewhat lower for the dividend tax rate), and very close to the baseline regressions in magnitude.

\subsection{Public finance}

Apart from corporate income taxes, we are also concerned about other features of the tax system. Changes to payout taxes may coincide with modifications to the tax code apart from the corporate tax rate. We therefore introduce a set of broad measures of public sector policy as covariates, which may make investment more profitable. More generally, this way we can address legislative endogeneity concerns: if firms with little internal equity increase investment following a payout tax reduction, is that because of the tax cut or did these firms just lobby to make the investment they were planning to do anyway more profitable? We collect alternative indicators of policy preferences for the economies in our sample from the World Development Indicators (World Bank, 2010). We opt for four indicators that measure government policy in three distinct dimensions: government stimulus, consumption climate, and legal environment. We sequentially include each policy control and its interaction with cash flow. To control for the effect of government stimulus programs that may affect investment we use control variables Subsidies, Grants, Social Benefits and Military Expenditure. The former measures government transfers on current account to private and public enterprises, and social security benefits in cash and in kind (relative to total government expense) (Table 12, Panel A). The latter includes all current and capital expenditures on the armed forces (relative to GDP) (Panel B). We measure governments' stance on consumption through control variable Sales and Turnover Tax. It measures the tax burden on goods and services relative to the value added of industry and services (Panel C). ${ }^{20}$ Finally, we measure public spending on research through $R \& D$ Expenditures as a fraction of GPD. It measures expenditures on basic research, applied research, and experimental development (Panel D). We use the more demanding flexible specifications to perform this additional check. Coverage for the world development indicators is generally poorer than for our tax variables over the sample period. In three of the four additional specifications the number of observations is at best half compared to our baseline specifications. Despite the reduction in sample size and the additional policy controls the coefficient for the cash flow*tax interaction remains strong and significant in most specifications.

\subsection{Substitutes for equity finance}

At the firm-level, a final source of concern is related to the source of external financing. Firms may try to substitute into debt funding of new investment if equity is expensive, as pointed out above (Section

${ }^{20}$ It includes general sales and turnover or value added taxes, selective taxes on services, taxes on the use of goods or property, taxes on extraction and production of minerals, and profits of fiscal monopolies. 
2.4). Presumably, not all firms are able to do so, e.g. because they cannot access debt markets or because their leverage is already high. Whether substitution into debt is prevalent enough to offset the predictions of our model is an empirical question. Looking at actual leverage, we find little effect of tax changes on book leverage ratios (Table A.XIII of the Appendix). This suggests that debt does not provide a complete substitute for equity finance. ${ }^{21}$

\subsection{Measurement error in $Q$}

Our final concern relates to the potential impact of measurement error in investment opportunities on our results (e.g., Almeida, Campello and Galvao, 2010; Erickson and Whited, 2000 and 2012). The empirical proxy for Tobin's q - the ratio of equity market value plus debt book value to book assets captures average Q, whereas marginal Q should be more closely related to investment opportunities. Also, the inputs used to calculate Q (e.g., the stock price) are noisy. Therefore, Q is likely a noisy measure of investment opportunities. The measurement error biases the coefficient on $\mathrm{Q}$ towards zero and the explanatory power loads on independent variables correlated with Q (in this case cash flow, which when interacted with taxation is the variable of interest). In our baseline, the coefficients on Q and on cash flow are possibly biased because of measurement error. However, under the assumption that measurement error in $\mathrm{Q}$ is not correlated with tax rates, our coefficient of interest (the interaction of cash flow and tax rates) is unbiased.

Even if this identifying assumption is plausible, we would like to address this more carefully. The literature identifies three estimators to remedy potential biases in regression coefficients due to measurement error in investment: instrumental variables (Almeida, Campello and Galvao, 2010; Rauh 2006), the dynamic panel estimators from Arellano and Bond (1991), and the high-order moment estimators due to Erickson and Whited (2000, 2002). Table 13 contains results for robustness to measurement error in $\mathrm{Q}$ for each estimator (the table only reports the coefficient of interest; each reported coefficient corresponds to a regression). In line with Almeida, Campello and Galvao (2010) we use Q lagged twice, and Q lagged twice and Cash Flow lagged twice, as instruments for investment for the first estimator (Almeida, Campello and Galvao, 2010). For the EW high-order moment estimator we present results for the third, fifth and seventh moment. In these latter specifications, we demean variables by

${ }^{21}$ We would also like to compare the response to taxes between firms with and without access to debt funding. For this, we would ideally sort firms based on unused debt capacity (predicting a smaller response for firms with good access to alternative funding). Unfortunately, this is challenging to implement empirically. Actual use of debt is not a priori a good candidate for estimating unused debt capacity. First, pecking order concerns will lead some firms to take on debt only if they have to, so that firms with high leverage may end up with less unused debt capacity than those with low leverage. A better measure would be something like the amount of unencumbered collateralizable assets, but this is not visible in the type of accounting data we have. 
country-year and by firm to account for firm- and country-year fixed effects. ${ }^{22}$ Coefficient estimates for the CashFlow*Tax interaction are quantitatively very similar to our baseline results for all three estimators, and highly statistically significant. These regression results raises our confidence that the baseline results are not driven by measurement error in Q.

\section{Conclusions}

Our results have three main implications. First, it appears that payout taxes drive the allocation of capital across firms. High taxes lock in capital in those firms that generate internal cash flows, ahead of those firms that need to raise outside equity. The cost of capital, especially for firms with much equity (low leverage), could be very sensitive to tax rates on payout for some firms, as well as heavily dependent on access to internal equity when payout taxes are high. We estimate economically large effects of payout taxes. This corresponds to recent trends in the amounts raised by various taxes. From 1960 to 2009, the share of corporate income taxes in aggregate U.S. Federal tax receipts fell from $24 \%$ to $10 \%$ (IRS 2009). A study by the Department of the Treasury, Office of Tax Analysis suggested that individual income taxes on dividends were $13 \%$ of Federal tax receipts in 2005. In other words, payout-related taxes may currently raise more revenue than corporate income taxes in the U.S.

Second, the impact on investment allocation makes payout taxes an important policy tool. If firms have different investment opportunities, our results mean that tax rates change the type of investments being made. Tax policy offers a tool for affecting the access to investment resources by firms without retained earnings. For example, high payout taxes may favor established industries while low taxes favor new industries.

Third, the well-known relation between cash flow and investment (see e.g. Fazzari, Hubbard, Petersen, 1988; Kaplan and Zingales, 1997; Lamont, 1997) may partially reflect the difference in the cost of capital between firms with and without access to inside equity. Firms invest more if they have easy access to more resources (see e.g. Lamont, 1997 and Rauh, 2006), especially internal cash flows. Our results point to a tax channel generating (a part of) this effect: having internal cash flows implies a lower after-tax cost of equity capital.

${ }^{22}$ The potential necessity of this adjustment is evident in, for example, Almeida, Campello and Galvao (2010, p. 3321), who highlight that "because real-world investment data contain firm-fixed effects and heteroskedasticity, the EW estimator delivers coefficients that are unstable across different specifications and not economically meaningful". Demeaning our dependent and independent variables, we create a dataset that takes fixed effects into consideration and at the same time fulfills the requirements of the EW estimator. 


\section{References}

Almeida, H., Campello, M., Weisbach, M.S., 2004. The Cash Flow Sensitivity of Cash. Journal of Finance 59, 1777-1804.

Almeida, H., Campello, M., Galvao, A.F., 2010. Measurement Errors in Investment Equations. Review of Financial Studies 23, 3279-3328.

Asquith, P., Mullins, D.W., 1986. Equity issues and offering dilution. Journal of Financial Economics 15, 61-89.

Arellano, M., Bond, S. 1991. Some Tests of Specification for Panel Data: Monte Carlo Evidence and an Application to Employment Equations. Review of Economic Studies 58, 277-297.

Auerbach, A.J., 1979a. Wealth maximization and the cost of capital. Quarterly Journal of Economics 93, 433-446.

Auerbach, A.J., 1979b. Share Valuation and Corporate Equity Policy. Journal of Public Economics 11, 291-305,

Baker, M.P., Stein, J.C., Wurgler, J.A., 2003. When Does the Market Matter? Stock Prices and the Investment of Equity-Dependent Firms. Quarterly Journal of Economics 118, 969-1006.

Becker, B., Ivković, Z., Weisbenner, S., 2011. Local Dividend Clienteles. Journal of Finance 66, 655683.

Bernheim, B.D., 1991. Tax Policy and the Dividend Puzzle. RAND Journal of Economics, 22, 455-476.

Bradford, D.F., 1981. The incidence and allocation effects of a tax on corporate distributions. Journal of Public Economics 15, 1-22.

Brown, J. R., Liang, N., Weisbenner, S., 2007. Executive Financial Incentives and Payout Policy: Firm Responses to the 2003 Dividend Tax Cut. Journal of Finance 62, 1935-1965.

Chen, H.-C., Ritter, J., 2000. The Seven Percent Solution. Journal of Finance 55, 1105-1131.

Chetty, R., Saez, E., 2005. Dividend Taxes and Corporate Behavior: Evidence from the 2003 Dividend Tax Cut. Quarterly Journal of Economics 120, 791-833.

Chetty, R., Saez, E., 2010. Dividend and Corporate Taxation in an Agency Model of the Firm. American Economic Journal: Economic Policy 2, 1-31.

Coase, R.H., 1937. The Nature of the Firm. Economica 4, 386-405.

DeRidder, A., 2009. Share Repurchases and Firm Behaviour. International Journal of Theoretical and Applied Finance 12, 605-631.

Dittmar, A., 2000. Why do Firms Repurchase Stock? Journal of Business 73, 331-355.

Djankov, S., Ganser, T., McLiesh, C., Ramalho, R., Shleifer, A., 2010. The Effect of Corporate Taxes on Investment and Entrepreneurship. American Economic Journal: Macroeconomics 2, 31-64.

Erickson, T., Whited, T.M., 2000. Measurement Error and the Relationship between Investment and q. Journal of Political Economy 108, 1027-1057.

Erickson, T., Whited, T.M., 2002. Two-Step GMM Estimation of the Errors-in-Variables Model using High-Order Moments. Econometric Theory 18, 776-799.

Erickson, T., Whited, T.M., 2012. Treating Measurement Error in Tobin's q. Review of Financial Studies 25, 1286-1329.

Fama, E.F., French, K.R., 2001. Disappearing dividends: changing firm characteristics or lower propensity to pay? Journal of Financial Economics 60, 3-43. 
Fazzari, S.M., Hubbard, R.G., Petersen, B., 1988. Finance Constraints and Corporate Investment. Brookings Papers on Economic Activity 1, 141-195.

Feldstein, M.S., 1970. Corporate Taxation and Dividend Behaviour. Review of Economic Studies 37, 5772.

French, K.R., Poterba, J.M., 1991. Investor Diversification and International Equity Markets. American Economic Review 81, 222-226.

Guenther, D.A., Sansing, R., 2006. Fundamentals of shareholder tax capitalization. Journal of Accounting and Economics 42, 371-383.

Hadlock, C. J. Pierce, J.R., 2010. New Evidence on Measuring Financial Constraints: Moving Beyond the KZ Index. Review of Financial Studies 23, 1909-1940.

Harberger, A.C., 1962. The Incidence of the Corporation Income Tax. Journal of Political Economy 70, 215-240.

Harberger, A.C., 1966. Efficiency effects of taxes on income from capital. In: Krzyzaniak, M. (Ed.), Effects of corporation income tax. Wayne State University Press, Detroit.

Hashimoto, M., 1998. Share Repurchases and Cancellation. Capital Market Trend Report 1998-17. Capital Market Research Group, Nomura Research Institute.

Internal Revenue Service, 2009, IRS Data Book 2009.

Jacob, M., Jacob, M. 2011. Taxation, Dividends, and Share Repurchases: Taking Evidence Global. Journal of Financial and Quantitative Analysis, forthcoming.

Jensen, M.C., Meckling, W.H., 1976. Theory of the Firm: Managerial Behavior, Agency Costs and Ownership Structure. Journal of Financial Economics 3, 305-360.

Jensen, M.C., Murphy, K.J., 1990. Performance Pay and Top-Management Incentives. Journal of Political Economy 98, 225-264.

Kaplan, S.N., Zingales, L., 1997. Do Investment-Cash Flow Sensitivities Provide Useful Measures of Financing Constraints? Quarterly Journal of Economics 112, 169-215.

King, M.A., 1977. Public Policy and the Corporation. Chapman and Hall, London.

Korinek, A., Stiglitz, J.E., 2009. Dividend Taxation and Intertemporal Tax Arbitrage. Journal of Public Economics 93, 142-159.

La Porta, R., Lopez-de-Silanes, F., Shleifer, A., Vishny, R.W., 2000. Agency Problems and Dividend Policies around the World. Journal of Finance 55, 1-33.

Lamont, O., 1997. Cash Flow and Investment: Evidence from Internal Capital Markets. Journal of Finance 52, 83-109.

Lewellen, J., Lewellen, K., 2006. Internal Equity, Taxes, and Capital Structure. Working Paper, Dartmouth.

Malmendier, U., Tate, G., 2005. CEO Overconfidence and Corporate Investment. Journal of Finance 60, 2661-2700.

Miller, M.H., Scholes, M.S., 1978. Dividends and taxes. Journal of Financial Economics 6, 333-364.

Mondria, J., Wu, T., 2010. The puzzling evolution of the home bias, information processing and financial openness. Journal of Economic Dynamics and Control 34, 875-896.

Myers, S.C., 1977. Determinants of Corporate Borrowing. Journal of Financial Economics 5, 147-175.

Organisation for Economic Co-Operation and Development (OECD). Tax Database, 2012. Available from: http://www.oecd.org/ctp/taxdatabase, assessed March, 2012. 
Perez-Gonzalez, F., 2003. Large Shareholders and Dividends: Evidence From U.S. Tax Reforms. Working Paper, Columbia University.

Poterba, J.M., 1987. Tax Policy and Corporate Savings. Brookings Papers on Economic Policy 2, 455503.

Poterba, J.M., 2004. Taxation and Corporate Payout Policy. American Economic Review 94, 171-175.

Poterba, J.M., Summers, L.H., 1984. New Evidence That Taxes Affect the Valuation of Dividends. Journal of Finance 39, 1397-1415.

Poterba, J.M., Summers, L.H., 1985. The Economic Effects of Dividend Taxation", In Altman, E., Subrahmanyam, M (Eds.), Recent advances in corporate finance. Dow Jones-Irwin Publishing: Homewood, IL, pp. 227-284.

Rau, P.R., Vermaelen, T., 2002. Regulation, Taxes, and Share Repurchases in the United Kingdom. Journal of Business 75, 245-282.

Rauh, J., 2006. Investment and Financing Constraints: Evidence from the Funding of Corporate Pension Plans. Journal of Finance 61, 33-71.

Rydqvist, K., Spizman, J., Strebulaev, I., 2010. The Evolution of Aggregate Stock Ownership. Working Paper.

Shleifer, A., Vishny, R.W., 1986. Large Shareholders and Corporate Control. Journal of Political Economy 94, 461-88.

Zingales, L., 2000. In Search of New Foundations. Journal of Finance 55, 1623-1653. 
Figure 1

Personal Tax Rates on Dividend Income - High Variation Countries

This figure shows dividend tax rates for the six countries in our sample with the largest within-country variation in personal income tax rates on dividend income over the 1990-2008 period.

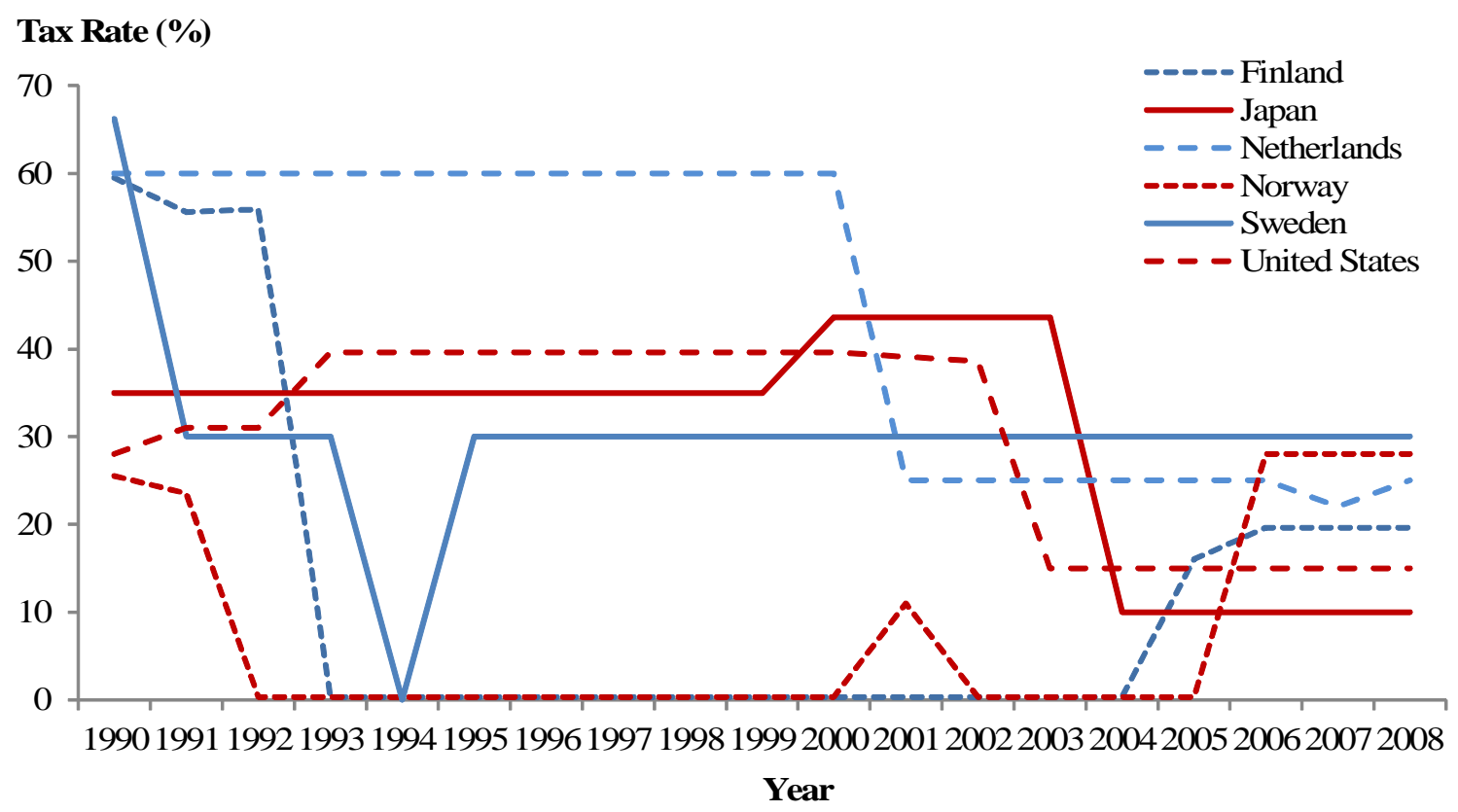

Figure 2

Capital Gains Tax Rates - High Variation Countries

This figure shows taxation of share repurchases for the six countries in our sample with the largest within-country variation in tax rates on capital gains over the 1990-2008 period.

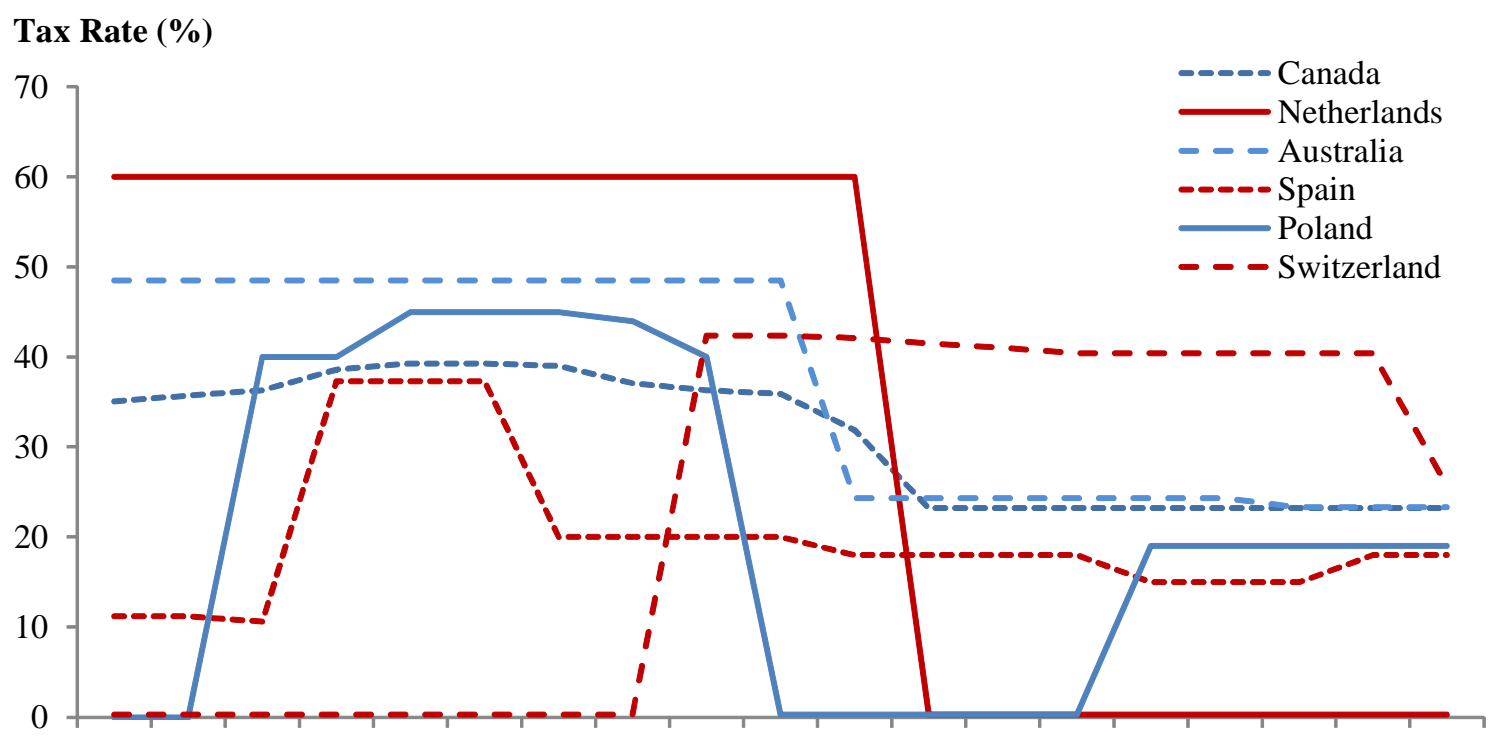

1990199119921993199419951996199719981999200020012002200320042005200620072008

Year 


\section{Figure 3}

\section{Tax Rates - Distribution over Sample}

This figure illustrates the distribution of tax rates across 81,222 observations in our sample over the 1990-2008 period. The graph is a transposed cumulative distribution function with number of observations on the $\mathrm{x}$-axis and tax rates on the y-axis. Dividend Taxis the personal income tax rate on dividends (in \%). Effective Tax C is the countryweighted effective corporate payout tax rate (in \%). It is obtained by weighting each year's dividend and effective capital gains tax rates by the relative importance of dividends and share repurchases as payout channels (relative to total corporate payout) in a country over the sample period. The effective tax rate on share repurchases equals onefourth of the statutory capital gains tax rate. Average $\operatorname{Tax} C$ is an alternative measure of the average corporate payout tax rate (in \%). It is calculated by weighting each year's dividend and statutory capital gains tax rates by the relative importance of dividends and share repurchases as payout channels (relative to total corporate payout) in a country over the sample period.






\section{Figure 4}

\section{Difference in Average Investment of High and Low Cash Flow Firm around Payout Tax Changes of at Least 3 Percentage Points, 1992-2006}

This figure shows differences in average investment between high cash flow firms and low cash flow firms for three years around 15 payout tax decreases and 14 payout tax increases in 1992-2006 with at least 30 observations in the country-year. We measure investment by capital expenditures normalized by prior-year total assets and demean investment by country-year cell. We sort firms in each country-year cell into five quintiles according to their cashflow, and calculate average investment for each quintile. The black line shows the difference in investment between high and low cash flow firms around payout tax increase events. The green line shows the difference in investment between high and low cash flow firms around payout tax decrease events. The 14 payout tax increase events are Australia 1993, Canada 1993, Denmark 1993 Denmark 2001, Germany 1994, Germany 1995, Finland 2005, Finland 2006, France 1997, Japan 2000, Norway 2006, Poland 2004, Switzerland 1998, and the US 1993. The 15 tax decrease events include Belgium 2002, Canada 1996, Canada 2001, Canada 2006, Germany 2001, France 2002, Italy 1998, Japan 2004, Netherlands 2001, Poland 2001, Spain 1996, Spain 1999, Spain 2003, US 1997, and the US 2003.

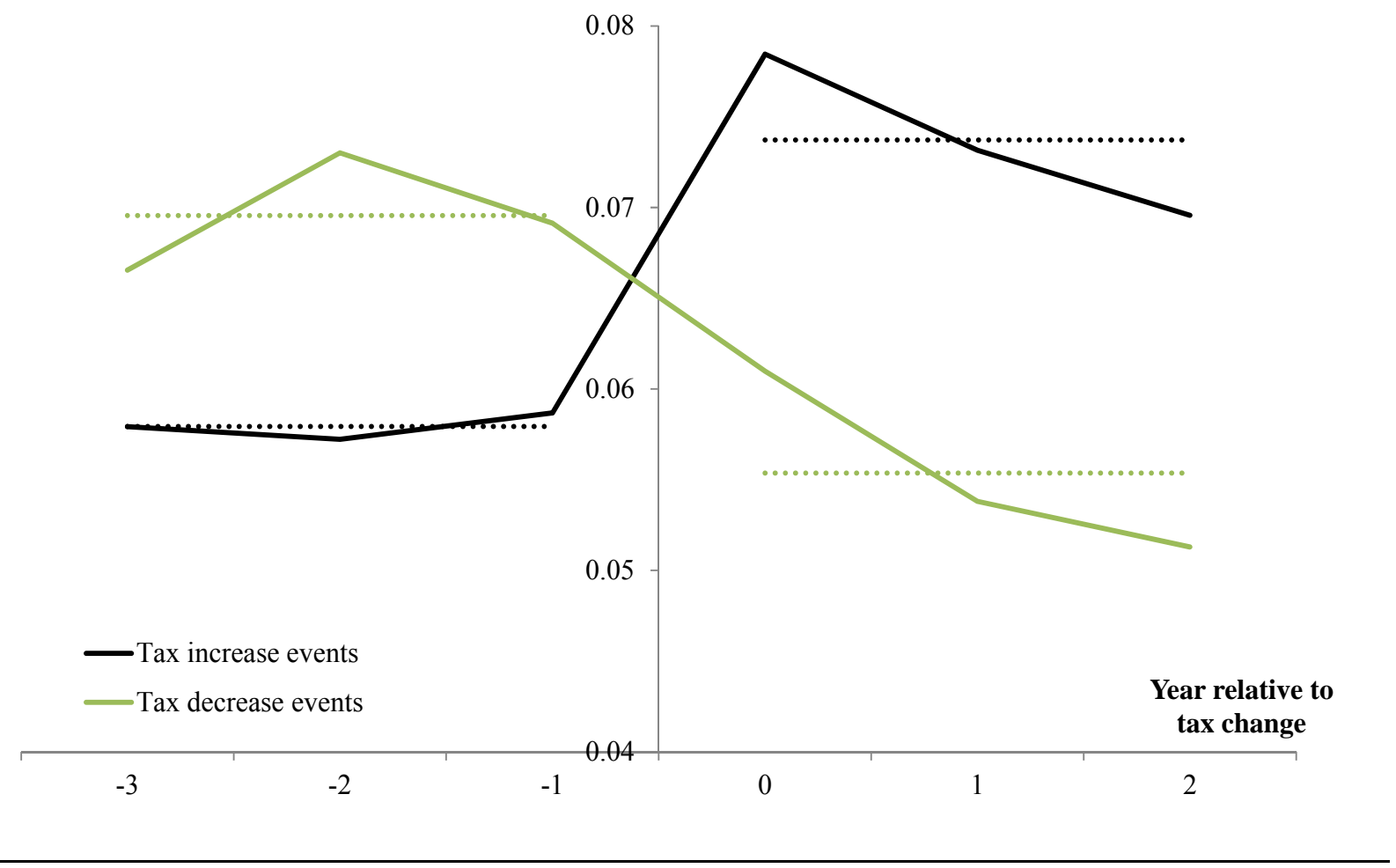




\section{Figure 5}

\section{Difference-in-Difference Estimates, Empirical Distribution}

This figure presents the empirical distribution of difference-in-difference estimates around tax increase and decrease events. Events are included if they represent a 3 percentage points or larger change in the tax rate, if there are at least 30 firm observations for each year around the change, and if they occur during 1992-2006. For each event, we sort firms in each year into five groups based on cash flows. For each year, the difference in the average investment to lagged assets between the firm quintiles with the highest and lowest cash flows is calculated. The difference-indifference estimate for each event is defined as the change in this difference from the three years before to the three year after the tax change. The graph presents tax decreases and increases separately.

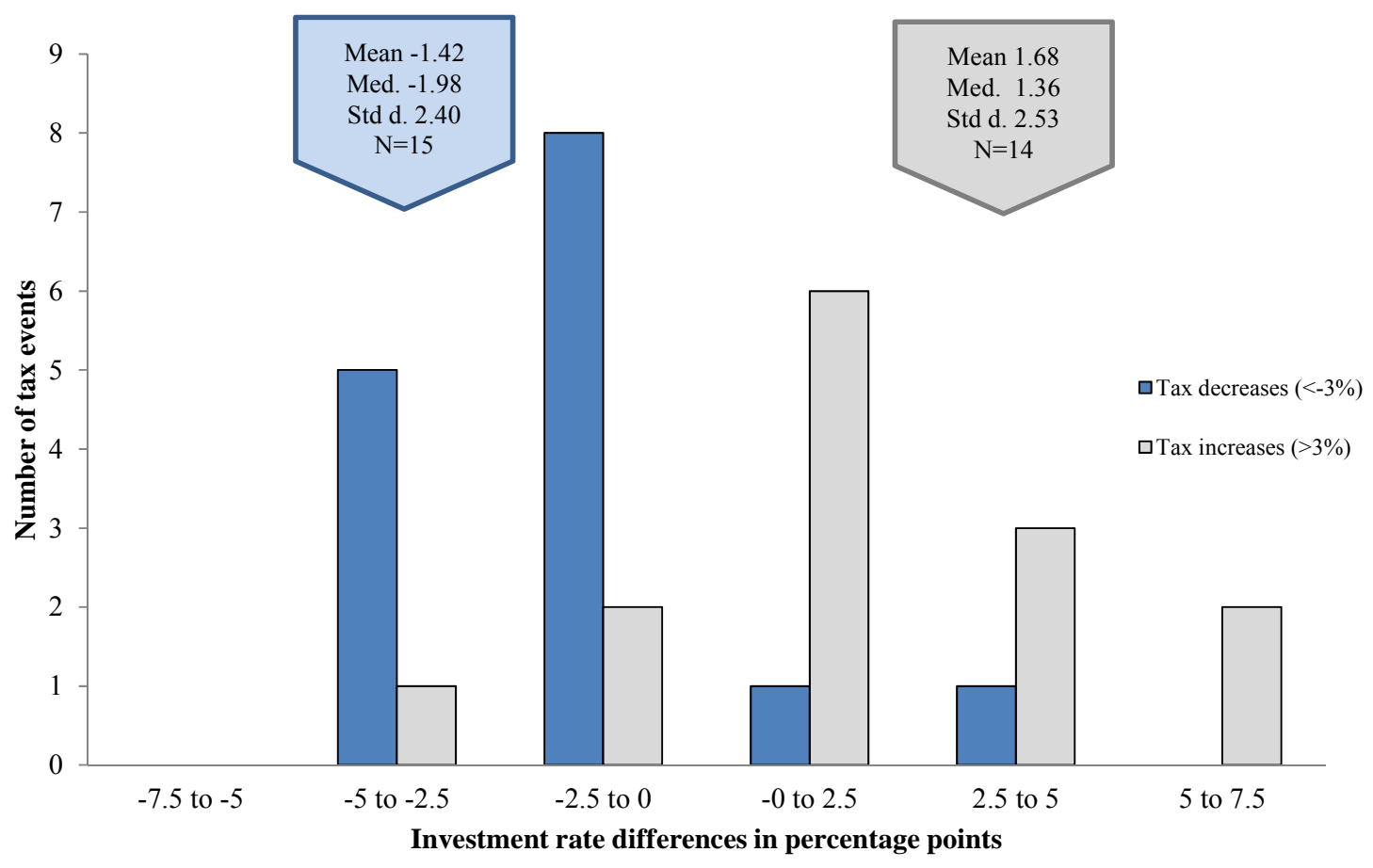


Table 1

Tax Regimes Across 25 Countries (1990-2008)

This table reports prevailing tax regimes across 25 countries over the 1990-2008 period. CL, FI, PI, SR, and TE abbreviate classical corporate taxation system, full imputation system, partial imputation system, shareholder relief system, and dividend tax exemption system, respectively. ${ }^{1}-$ Split-rate system for distributed and retained earnings. ${ }^{2}$ - Individuals had the option to accumulate the dividend grossed up applying a factor of 1.82 combined with a tax credit of $35 \%$ on the grossed up dividend. This mechanism is similar to a full imputation system (Source: OECD).

\begin{tabular}{|c|c|c|c|c|c|c|c|c|c|c|c|c|c|c|c|c|c|c|c|}
\hline Country & 1990 & 1991 & 1992 & 1993 & 1994 & 1995 & 1996 & 1997 & 1998 & 1999 & 2000 & 2001 & 2002 & 2003 & 2004 & 2005 & 2006 & 2007 & 2008 \\
\hline Australia & FI & FI & FI & FI & FI & FI & FI & FI & FI & FI & FI & FI & FI & FI & FI & FI & FI & FI & FI \\
\hline Austria & SR & SR & SR & SR & SR & SR & SR & SR & SR & SR & SR & SR & SR & SR & SR & SR & SR & SR & SR \\
\hline Belgium & SR & SR & SR & SR & SR & SR & SR & SR & SR & SR & SR & SR & SR & SR & SR & SR & SR & SR & SR \\
\hline Canada & PI & PI & PI & PI & PI & PI & PI & PI & PI & PI & PI & PI & PI & PI & PI & PI & PI & PI & PI \\
\hline Denmark & $\mathrm{CL}$ & CL & $\mathrm{CL}$ & $\mathrm{CL}$ & $\mathrm{CL}$ & $\mathrm{CL}$ & CL & $\mathrm{CL}$ & $\mathrm{CL}$ & $\mathrm{CL}$ & $\mathrm{CL}$ & CL & $\mathrm{CL}$ & CL & CL & SR & SR & SR & SR \\
\hline Finland & PI & PI & PI & FI & FI & FI & FI & FI & FI & FI & FI & FI & FI & FI & FI & SR & SR & SR & SR \\
\hline France & FI & FI & FI & FI & FI & FI & FI & FI & FI & FI & FI & FI & FI & FI & FI & SR & SR & SR & SR \\
\hline Germany & $\mathrm{FI}^{1}$ & $\mathrm{FI}^{1}$ & $\mathrm{FI}^{1}$ & $\mathrm{FI}^{1}$ & $\mathrm{FI}^{1}$ & $\mathrm{FI}^{1}$ & $\mathrm{FI}^{1}$ & $\mathrm{FI}^{1}$ & $\mathrm{FI}^{1}$ & $\mathrm{FI}^{1}$ & $\mathrm{FI}^{1}$ & SR & SR & SR & SR & SR & SR & SR & SR \\
\hline Greece & - & - & TE & $\mathrm{TE}$ & $\mathrm{TE}$ & $\mathrm{TE}$ & $\mathrm{TE}$ & $\mathrm{TE}$ & $\mathrm{TE}$ & $\mathrm{TE}$ & $\mathrm{TE}$ & $\mathrm{TE}$ & $\mathrm{TE}$ & $\mathrm{TE}$ & $\mathrm{TE}$ & $\mathrm{TE}$ & $\mathrm{TE}$ & $\mathrm{TE}$ & $\mathrm{TE}$ \\
\hline Hungary & SR & SR & SR & SR & SR & SR & SR & SR & SR & SR & SR & SR & SR & SR & SR & SR & SR & SR & $\mathrm{SR}$ \\
\hline Ireland & PI & PI & PI & PI & PI & PI & PI & PI & PI & PI & $\mathrm{CL}$ & $\mathrm{CL}$ & $\mathrm{CL}$ & CL & $\mathrm{CL}$ & $\mathrm{CL}$ & CL & $\mathrm{CL}$ & CL \\
\hline Italy & FI & FI & FI & FI & FI & FI & FI & FI & SR & SR & SR & SR & SR & SR & SR & SR & SR & SR & SR \\
\hline Japan & $\mathrm{CL}$ & $\mathrm{CL}$ & $\mathrm{CL}$ & $\mathrm{CL}$ & $\mathrm{CL}$ & $\mathrm{CL}$ & $\mathrm{CL}$ & $\mathrm{CL}$ & SR & SR & SR & SR & SR & SR & SR & SR & SR & SR & SR \\
\hline Korea & PI & PI & PI & PI & PI & PI & PI & PI & PI & PI & PI & PI & PI & PI & PI & PI & PI & PI & PI \\
\hline Mexico & $\mathrm{FI}^{2}$ & $\mathrm{FI}^{2}$ & $\mathrm{TE}$ & $\mathrm{TE}$ & TE & TE & TE & TE & $\mathrm{TE}$ & FI & FI & FI & FI & $\mathrm{FI}$ & FI & FI & FI & FI & FI \\
\hline Netherlands & $\mathrm{CL}$ & $\mathrm{CL}$ & $\mathrm{CL}$ & $\mathrm{CL}$ & $\mathrm{CL}$ & $\mathrm{CL}$ & $\mathrm{CL}$ & $\mathrm{CL}$ & $\mathrm{CL}$ & $\mathrm{CL}$ & $\mathrm{CL}$ & SR & SR & SR & SR & SR & SR & SR & SR \\
\hline New Zealand & FI & FI & FI & FI & FI & FI & FI & FI & FI & FI & FI & FI & FI & FI & FI & FI & FI & FI & FI \\
\hline Norway & SR & SR & FI & FI & FI & FI & FI & FI & FI & FI & FI & PI & FI & FI & FI & FI & SR & SR & SR \\
\hline Poland & - & - & - & SR & SR & SR & SR & SR & SR & SR & $\mathrm{SR}$ & SR & SR & $\mathrm{SR}$ & SR & SR & SR & SR & SR \\
\hline Portugal & $\mathrm{SR}$ & SR & SR & SR & SR & $\mathrm{SR}$ & SR & SR & SR & SR & SR & SR & SR & SR & SR & SR & SR & SR & SR \\
\hline Spain & $\mathrm{CL}$ & $\mathrm{CL}$ & $\mathrm{CL}$ & $\mathrm{CL}$ & $\mathrm{CL}$ & PI & PI & PI & PI & PI & PI & PI & PI & PI & PI & PI & PI & SR & SR \\
\hline Sweden & $\mathrm{CL}$ & SR & $\mathrm{SR}$ & SR & SR & SR & SR & SR & SR & SR & SR & SR & SR & SR & SR & SR & SR & SR & SR \\
\hline Switzerland & $\mathrm{CL}$ & $\mathrm{CL}$ & $\mathrm{CL}$ & $\mathrm{CL}$ & $\mathrm{CL}$ & $\mathrm{CL}$ & $\mathrm{CL}$ & $\mathrm{CL}$ & $\mathrm{CL}$ & $\mathrm{CL}$ & $\mathrm{CL}$ & $\mathrm{CL}$ & $\mathrm{CL}$ & $\mathrm{CL}$ & $\mathrm{CL}$ & $\mathrm{CL}$ & CL & SR & SR \\
\hline United Kingdom & PI & PI & PI & PI & PI & PI & PI & PI & PI & PI & PI & PI & PI & PI & PI & PI & PI & PI & PI \\
\hline United States & $\mathrm{CL}$ & $\mathrm{CL}$ & $\mathrm{CL}$ & $\mathrm{CL}$ & $\mathrm{CL}$ & $\mathrm{CL}$ & $\mathrm{CL}$ & $\mathrm{CL}$ & $\mathrm{CL}$ & $\mathrm{CL}$ & $\mathrm{CL}$ & $\mathrm{CL}$ & $\mathrm{CL}$ & SR & SR & SR & SR & SR & $\mathrm{SR}$ \\
\hline
\end{tabular}


Table 2

Personal Income Tax Rates and Capital Gains Tax Rates Across 25 Countries (1990-2008)

This table shows effective corporate payout tax rates across 25 countries over the 1990-2008 period. Panel A reports personal income tax rates on dividend income (in \%). Panel B reports capital gains tax rates (in \%). All capital gains tax rates reported are effective rates incurred by investors with non-substantial shareholdings and holding periods that qualify as long-term investments in accordance with country-specific tax legislation. For example in Denmark, Germany or the United States, capital gains from long-term shareholdings are taxed at the lower rate reported in Panel B. Austria, Italy, and Netherlands are examples for countries where capital gains from substantial shareholdings are taxed at higher rates. A shareholding qualifies as substantial if it exceeds a certain threshold in share capital (for example 5\% in the Netherlands). See Jacob and Jacob (2011) for a detailed description of applied tax rates.

\begin{tabular}{|c|c|c|c|c|c|c|c|c|c|c|c|c|c|c|c|c|c|c|c|}
\hline \multicolumn{20}{|c|}{ Panel A: Personal Income Tax Rates on Dividend Income (in \%) } \\
\hline Country & 1990 & 1991 & 1992 & 1993 & 1994 & 1995 & 1996 & 1997 & 1998 & 1999 & 2000 & 2001 & 2002 & 2003 & 2004 & 2005 & 2006 & 2007 & 2008 \\
\hline Australia & 15.2 & 15.2 & 15.2 & 23.0 & 23.0 & 19.5 & 19.5 & 19.5 & 19.5 & 19.5 & 22.0 & 26.4 & 26.4 & 26.4 & 26.4 & 26.4 & 23.6 & 23.6 & 23.6 \\
\hline Austria & 25.0 & 25.0 & 25.0 & 25.0 & 22.0 & 22.0 & 22.0 & 25.0 & 25.0 & 25.0 & 25.0 & 25.0 & 25.0 & 25.0 & 25.0 & 25.0 & 25.0 & 25.0 & 25.0 \\
\hline Belgium & 25.0 & 25.0 & 25.0 & 25.0 & 25.0 & 15.0 & 15.0 & 15.0 & 15.0 & 15.0 & 15.0 & 15.0 & 15.0 & 15.0 & 15.0 & 15.0 & 15.0 & 15.0 & 15.0 \\
\hline Canada & 38.3 & 39.1 & 40.1 & 43.5 & 44.6 & 44.6 & 37.0 & 35.8 & 34.6 & 33.6 & 33.2 & 31.9 & 31.9 & 31.9 & 31.9 & 31.9 & 24.4 & 24.1 & 23.6 \\
\hline Denmark & 60.9 & 45.0 & 45.0 & 40.0 & 40.0 & 40.0 & 40.0 & 40.0 & 40.0 & 40.0 & 40.0 & 43.0 & 43.0 & 43.0 & 43.0 & 43.0 & 43.0 & 43.0 & 45.0 \\
\hline Finland & 59.5 & 55.6 & 55.9 & 0.0 & 0.0 & 0.0 & 0.0 & 0.0 & 0.0 & 0.0 & 0.0 & 0.0 & 0.0 & 0.0 & 0.0 & 16.0 & 19.6 & 19.6 & 19.6 \\
\hline France & 39.9 & 39.9 & 39.9 & 41.8 & 41.8 & 42.6 & 39.0 & 43.4 & 41.9 & 41.9 & 40.8 & 40.1 & 35.6 & 33.5 & 33.9 & 32.3 & 32.7 & 32.7 & 32.7 \\
\hline Germany & 26.6 & 29.7 & 29.7 & 26.6 & 32.9 & 38.5 & 38.5 & 38.5 & 37.0 & 37.0 & 34.0 & 25.6 & 25.6 & 25.6 & 23.7 & 22.2 & 22.2 & 23.7 & 26.4 \\
\hline Greece & - & - & 0.0 & 0.0 & 0.0 & 0.0 & 0.0 & 0.0 & 0.0 & 0.0 & 0.0 & 0.0 & 0.0 & 0.0 & 0.0 & 0.0 & 0.0 & 0.0 & 0.0 \\
\hline Hungary & 20.0 & 20.0 & 10.0 & 10.0 & 10.0 & 10.0 & 10.0 & 10.0 & 20.0 & 20.0 & 20.0 & 20.0 & 20.0 & 20.0 & 20.0 & 25.0 & 25.0 & 10.0 & 10.0 \\
\hline Ireland & 35.8 & 35.7 & 32.0 & 30.7 & 30.7 & 32.0 & 32.5 & 34.4 & 39.3 & 39.3 & 44.0 & 42.0 & 42.0 & 42.0 & 42.0 & 42.0 & 42.0 & 41.0 & 41.0 \\
\hline Italy & 21.9 & 21.9 & 23.4 & 23.4 & 23.4 & 23.4 & 22.2 & 22.2 & 12.5 & 12.5 & 12.5 & 12.5 & 12.5 & 12.5 & 12.5 & 12.5 & 12.5 & 12.5 & 12.5 \\
\hline Japan & 35.0 & 35.0 & 35.0 & 35.0 & 35.0 & 35.0 & 35.0 & 35.0 & 35.0 & 35.0 & 43.6 & 43.6 & 43.6 & 43.6 & 10.0 & 10.0 & 10.0 & 10.0 & 10.0 \\
\hline Korea & 47.3 & 47.3 & 47.3 & 47.3 & 38.4 & 37.0 & 33.4 & 33.4 & 33.4 & 22.7 & 22.7 & 33.4 & 28.1 & 28.1 & 28.1 & 31.1 & 31.1 & 31.1 & 31.1 \\
\hline Mexico & 0.0 & 0.0 & 0.0 & 0.0 & 0.0 & 0.0 & 0.0 & 0.0 & 0.0 & 0.0 & 0.0 & 0.0 & 0.0 & 0.0 & 0.0 & 0.0 & 0.0 & 0.0 & 0.0 \\
\hline Netherlands & 60.0 & 60.0 & 60.0 & 60.0 & 60.0 & 60.0 & 60.0 & 60.0 & 60.0 & 60.0 & 60.0 & 25.0 & 25.0 & 25.0 & 25.0 & 25.0 & 25.0 & 22.0 & 25.0 \\
\hline New Zealand & 0.0 & 0.0 & 0.0 & 0.0 & 0.0 & 0.0 & 0.0 & 0.0 & 0.0 & 0.0 & 8.9 & 8.9 & 8.9 & 8.9 & 8.9 & 8.9 & 9.0 & 8.9 & 12.9 \\
\hline Norway & 25.5 & 23.5 & 0.0 & 0.0 & 0.0 & 0.0 & 0.0 & 0.0 & 0.0 & 0.0 & 0.0 & 11.0 & 0.0 & 0.0 & 0.0 & 0.0 & 28.0 & 28.0 & 28.0 \\
\hline Poland & - & - & - & 20.0 & 20.0 & 20.0 & 20.0 & 20.0 & 20.0 & 20.0 & 20.0 & 15.0 & 15.0 & 15.0 & 19.0 & 19.0 & 19.0 & 19.0 & 19.0 \\
\hline Portugal & 25.0 & 25.0 & 25.0 & 25.0 & 25.0 & 25.0 & 25.0 & 25.0 & 25.0 & 25.0 & 25.0 & 25.0 & 20.0 & 20.0 & 20.0 & 20.0 & 20.0 & 20.0 & 20.0 \\
\hline Spain & 46.0 & 46.0 & 43.0 & 46.0 & 46.0 & 38.4 & 38.4 & 38.4 & 38.4 & 27.2 & 27.2 & 27.2 & 27.2 & 23.0 & 23.0 & 23.0 & 23.0 & 18.0 & 18.0 \\
\hline Sweden & 66.2 & 30.0 & 30.0 & 30.0 & 0.0 & 30.0 & 30.0 & 30.0 & 30.0 & 30.0 & 30.0 & 30.0 & 30.0 & 30.0 & 30.0 & 30.0 & 30.0 & 30.0 & 30.0 \\
\hline Switzerland & 40.9 & 40.9 & 41.5 & 42.4 & 42.4 & 42.4 & 42.4 & 42.4 & 42.4 & 42.4 & 42.1 & 41.5 & 41.0 & 40.4 & 40.4 & 40.4 & 40.4 & 40.4 & 25.7 \\
\hline United Kingdom & 20.0 & 20.0 & 20.0 & 22.6 & 25.0 & 25.0 & 25.0 & 25.0 & 25.0 & 25.0 & 25.0 & 25.0 & 25.0 & 25.0 & 25.0 & 25.0 & 25.0 & 25.0 & 25.0 \\
\hline United States & 28.0 & 31.0 & 31.0 & 39.6 & 39.6 & 39.6 & 39.6 & 39.6 & 39.6 & 39.6 & 39.6 & 39.1 & 38.6 & 15.0 & 15.0 & 15.0 & 15.0 & 15.0 & 15.0 \\
\hline
\end{tabular}


Panel B: Capital Gains Tax Rates (in \%)

\begin{tabular}{|c|c|c|c|c|c|c|c|c|c|c|c|c|c|c|c|c|c|c|c|}
\hline Country & 1990 & 1991 & 1992 & 1993 & 1994 & 1995 & 1996 & 1997 & 1998 & 1999 & 2000 & 2001 & 2002 & 2003 & 2004 & 2005 & 2006 & 2007 & 2008 \\
\hline Australia & 48.5 & 48.5 & 48.5 & 48.5 & 48.5 & 48.5 & 48.5 & 48.5 & 48.5 & 48.5 & 24.3 & 24.3 & 24.3 & 24.3 & 24.3 & 24.3 & 23.3 & 23.3 & 23.3 \\
\hline Austria & 0.0 & 0.0 & 0.0 & 0.0 & 0.0 & 0.0 & 0.0 & 0.0 & 0.0 & 0.0 & 0.0 & 0.0 & 0.0 & 0.0 & 0.0 & 0.0 & 0.0 & 0.0 & 0.0 \\
\hline Belgium & 41.0 & 39.0 & 39.0 & 40.2 & 40.2 & 40.2 & 40.2 & 40.2 & 40.2 & 40.2 & 40.2 & 40.2 & 10.0 & 10.0 & 10.0 & 10.0 & 10.0 & 10.0 & 10.0 \\
\hline Canada & 35.1 & 35.7 & 36.3 & 38.6 & 39.3 & 39.3 & 39.0 & 37.1 & 36.3 & 35.9 & 31.9 & 23.2 & 23.2 & 23.2 & 23.2 & 23.2 & 23.2 & 23.2 & 23.2 \\
\hline Denmark & 0.0 & 0.0 & 0.0 & 40.0 & 40.0 & 40.0 & 40.0 & 40.0 & 40.0 & 40.0 & 40.0 & 43.0 & 43.0 & 43.0 & 43.0 & 43.0 & 43.0 & 43.0 & 45.0 \\
\hline Finland & 23.8 & 27.8 & 27.9 & 25.0 & 25.0 & 25.0 & 28.0 & 28.0 & 28.0 & 28.0 & 29.0 & 29.0 & 29.0 & 29.0 & 29.0 & 28.0 & 28.0 & 28.0 & 28.0 \\
\hline France & 19.4 & 19.4 & 19.4 & 19.4 & 19.4 & 19.4 & 19.4 & 19.9 & 19.9 & 26.0 & 26.0 & 26.0 & 26.0 & 26.0 & 26.0 & 27.0 & 27.0 & 27.0 & 30.1 \\
\hline Germany & 0.0 & 0.0 & 0.0 & 0.0 & 0.0 & 0.0 & 0.0 & 0.0 & 0.0 & 0.0 & 0.0 & 0.0 & 0.0 & 0.0 & 0.0 & 0.0 & 0.0 & 0.0 & 0.0 \\
\hline Greece & - & - & - & 0.0 & 0.0 & 0.0 & 0.0 & 0.0 & 0.0 & 0.0 & 0.0 & 0.0 & 0.0 & 0.0 & 0.0 & 0.0 & 0.0 & 0.0 & 0.0 \\
\hline Hungary & 20.0 & 20.0 & 20.0 & 20.0 & 20.0 & 10.0 & 10.0 & 10.0 & 20.0 & 20.0 & 20.0 & 20.0 & 20.0 & 20.0 & 0.0 & 0.0 & 20.0 & 20.0 & 20.0 \\
\hline Ireland & 40.0 & 40.0 & 40.0 & 40.0 & 40.0 & 40.0 & 40.0 & 40.0 & 20.0 & 20.0 & 20.0 & 20.0 & 20.0 & 20.0 & 20.0 & 20.0 & 20.0 & 20.0 & 20.0 \\
\hline Italy & 25.0 & 25.0 & 25.0 & 25.0 & 25.0 & 25.0 & 25.0 & 25.0 & 12.5 & 12.5 & 12.5 & 12.5 & 12.5 & 12.5 & 12.5 & 12.5 & 12.5 & 12.5 & 12.5 \\
\hline Japan & 35.0 & 35.0 & 35.0 & 35.0 & 35.0 & 26.0 & 26.0 & 26.0 & 26.0 & 26.0 & 26.0 & 26.0 & 26.0 & 26.0 & 10.0 & 10.0 & 10.0 & 10.0 & 10.0 \\
\hline Korea & 0.0 & 0.0 & 0.0 & 0.0 & 0.0 & 0.0 & 0.0 & 0.0 & 0.0 & 0.0 & 0.0 & 0.0 & 0.0 & 0.0 & 0.0 & 0.0 & 0.0 & 0.0 & 0.0 \\
\hline Mexico & 0.0 & 0.0 & 0.0 & 0.0 & 0.0 & 0.0 & 0.0 & 0.0 & 0.0 & 0.0 & 0.0 & 0.0 & 0.0 & 0.0 & 0.0 & 0.0 & 0.0 & 0.0 & 0.0 \\
\hline Netherlands & 60.0 & 60.0 & 60.0 & 60.0 & 60.0 & 60.0 & 60.0 & 60.0 & 60.0 & 60.0 & 60.0 & 0.0 & 0.0 & 0.0 & 0.0 & 0.0 & 0.0 & 0.0 & 0.0 \\
\hline New Zealand & 0.0 & 0.0 & 0.0 & 0.0 & 0.0 & 0.0 & 0.0 & 0.0 & 0.0 & 0.0 & 0.0 & 0.0 & 0.0 & 0.0 & 0.0 & 0.0 & 0.0 & 0.0 & 0.0 \\
\hline Norway & 0.0 & 0.0 & 0.0 & 0.0 & 0.0 & 0.0 & 0.0 & 0.0 & 0.0 & 0.0 & 0.0 & 0.0 & 0.0 & 0.0 & 0.0 & 0.0 & 28.0 & 28.0 & 28.0 \\
\hline Poland & - & - & 40.0 & 40.0 & 45.0 & 45.0 & 45.0 & 44.0 & 40.0 & 0.0 & 0.0 & 0.0 & 0.0 & 0.0 & 19.0 & 19.0 & 19.0 & 19.0 & 19.0 \\
\hline Portugal & 0.0 & 0.0 & 0.0 & 0.0 & 0.0 & 0.0 & 0.0 & 0.0 & 0.0 & 0.0 & 0.0 & 0.0 & 0.0 & 0.0 & 0.0 & 0.0 & 0.0 & 0.0 & 0.0 \\
\hline Spain & 11.2 & 11.2 & 10.6 & 37.3 & 37.3 & 37.3 & 20.0 & 20.0 & 20.0 & 20.0 & 18.0 & 18.0 & 18.0 & 18.0 & 15.0 & 15.0 & 15.0 & 18.0 & 18.0 \\
\hline Sweden & 33.1 & 30.0 & 25.0 & 25.0 & 12.5 & 30.0 & 30.0 & 30.0 & 30.0 & 30.0 & 30.0 & 30.0 & 30.0 & 30.0 & 30.0 & 30.0 & 30.0 & 30.0 & 30.0 \\
\hline Switzerland & 0.0 & 0.0 & 0.0 & 0.0 & 0.0 & 0.0 & 0.0 & 0.0 & 42.4 & 42.4 & 42.1 & 41.5 & 41.0 & 40.4 & 40.4 & 40.4 & 40.4 & 40.4 & 25.7 \\
\hline United Kingdom & 40.0 & 40.0 & 40.0 & 40.0 & 40.0 & 40.0 & 40.0 & 40.0 & 40.0 & 40.0 & 40.0 & 40.0 & 40.0 & 40.0 & 40.0 & 40.0 & 40.0 & 40.0 & 18.0 \\
\hline United States & 28.0 & 28.0 & 28.0 & 28.0 & 28.0 & 28.0 & 28.0 & 20.0 & 20.0 & 20.0 & 20.0 & 20.0 & 20.0 & 15.0 & 15.0 & 15.0 & 15.0 & 15.0 & 15.0 \\
\hline
\end{tabular}




\section{Table 3}

\section{Sample Overview and Summary Statistics}

The sample consists of 7,661 firms in 25 countries for 1990-2008 presented in Panel A. Summary statistics for investment variables are presented in Panel B. Investment refers to capital expenditure in year $t$ divided by the endof-year $t$ - 1 assets. PPE Growth refers to growth in plant, property, and equipment from $t$ - 1 to $t$ divided by the endof-year $t-1$ assets, and Asset Growth is defined as the growth rate of assets over the prior year. Summary statistics for independent variables are presented in Panel C. Dividend Taxis the personal income tax rate on dividends (in \%).Effective Tax $C$ is the country-weighted effective corporate payout tax rate (in \%). It is obtained by weighting each year's dividend and effective capital gains tax rates by the relative importance of dividends and share repurchases as payout channels (relative to total corporate payout) in a country over the sample period. The effective tax rate on share repurchases equals one-fourth of the statutory capital gains tax rate. Average Tax C is an alternative measure of the average corporate payout tax rate (in \%). It is calculated by weighting each year's dividend and statutory capital gains tax rates by the relative importance of dividends and share repurchases as payout channels (relative to total corporate payout) in a country over the sample period. Cash Flow is the ratio of cash flow in year $t$ relative to prior year total assets. Cash is defined as cash holdings over prior year assets. EBITDA measures earnings before interest, tax, and depreciation in year $t$ as a fraction of $t-1$ total assets. $Q$ is defined as the market-to-book ratio, that is, the market value divided by the replacement value of the physical assets of a firm. Sales Growth is the logarithm of the growth rate of sales from $t-2$ to $t$. Leverage is the ratio of year $t$ total debt to prior year total assets, and Size is the relative firm size measured as the percentage of firms in the sample that are smaller than this firm. All variables are in real USD (base year 2000).

\begin{tabular}{|c|c|c|c|c|c|c|c|c|}
\hline \multicolumn{9}{|c|}{ Panel A: Sample Overview } \\
\hline \multirow{2}{*}{$\frac{\text { Country }}{\text { Australia }}$} & \multirow{2}{*}{$\begin{array}{r}\mathrm{N}(\text { Firms }) \\
261\end{array}$} & \multirow{2}{*}{$\begin{array}{r}\mathrm{N}(\mathrm{Obs}) \\
1,879\end{array}$} & \multirow{2}{*}{$\begin{array}{l}\text { Country } \\
\text { Hungary }\end{array}$} & \multirow{2}{*}{$\frac{\mathrm{N}(\text { Firms }) \mathrm{N}}{13}$} & \multirow{2}{*}{$\frac{\mathrm{N}(\mathrm{Obs})}{111}$} & \multirow{2}{*}{$\begin{array}{l}\text { Country } \\
\text { Poland }\end{array}$} & \multicolumn{2}{|c|}{$\mathrm{N}($ Firms $) \mathrm{N}(\mathrm{Obs})$} \\
\hline & & & & & & & 70 & 403 \\
\hline Austria & 26 & 332 & Ireland & 18 & 252 & Portugal & 28 & 269 \\
\hline Belgium & 38 & 463 & Italy & 66 & 925 & Spain & 41 & 577 \\
\hline Canada & 320 & 2,525 & Japan & $2,071 \quad 22$ & 22,347 & Sweden & 100 & 1,112 \\
\hline Denmark & 65 & 867 & Korea & 477 & 4,528 & Switzerland & 85 & 1,136 \\
\hline Finland & 57 & 727 & Mexico & 39 & 401 & UK & 470 & 6,054 \\
\hline France & 212 & 2,608 & Netherlands & 68 & 894 & USA & 2,720 & 28,439 \\
\hline Germany & 245 & 3,067 & New Zealand & 31 & 272 & Total & 7,661 & 81,222 \\
\hline Greece & 99 & 519 & Norway & 41 & 515 & & & \\
\hline \multicolumn{9}{|c|}{ Panel B: Summary Statistics for Investment } \\
\hline & & $\mathrm{N}$ & Mean & $\begin{array}{c}\text { Standard } \\
\text { Deviation }\end{array}$ & $\begin{array}{ll}\mathrm{d} & \\
\mathrm{O} & \mathrm{P}\end{array}$ & $\begin{array}{l}10^{\text {th }} \\
\text { ercentile }\end{array}$ & Median & $\begin{array}{c}90^{\text {th }} \\
\text { Percentile }\end{array}$ \\
\hline Investment & & 81,222 & 0.0594 & 0.0676 & & 0.0083 & 0.0398 & 0.1271 \\
\hline PPE Growth & & 77,626 & 0.0805 & 0.2364 & & -0.1377 & 0.0514 & 0.2898 \\
\hline Asset Growth & & 81,222 & 0.0785 & 0.3128 & & -0.1702 & 0.0338 & 0.3079 \\
\hline & & Panel C: & Summary St & stics for In & Indepe & ndent Varia & bles & \\
\hline & & $\mathrm{N}$ & Mean & St. Dev. & & $10^{\text {th }} \%$ & Median & $90^{\text {th }} \%$ \\
\hline Dividend Tax & & 81,222 & 27.7640 & 12.5679 & & 10.0000 & 30.0000 & 43.6000 \\
\hline Effective Tax C & & 81,222 & 18.2530 & 9.1225 & & 7.6536 & 17.5143 & 31.9932 \\
\hline Average Tax C & & 81,222 & 24.1584 & 10.3002 & & 10.0000 & 26.9082 & 38.0938 \\
\hline Cash Flow & & 81,222 & 0.0696 & 0.1043 & & -0.0217 & 0.0720 & 0.1767 \\
\hline Cash & & 81,222 & 0.1480 & 0.1883 & & 0.0127 & 0.0922 & 0.3409 \\
\hline EBITDA & & 81,222 & 0.0957 & 0.1139 & & -0.0066 & 0.1008 & 0.2138 \\
\hline Q & & 81,222 & 2.1270 & 2.9255 & & 0.7524 & 1.2183 & 4.0391 \\
\hline Sales Growth & & 81,222 & 0.1114 & 0.3924 & & -0.2719 & 0.0896 & 0.5080 \\
\hline Leverage & & 81,222 & 0.2607 & 0.2345 & & 0.0031 & 0.2276 & 0.5313 \\
\hline Size & & 81,222 & 0.6306 & 0.2404 & & 0.2800 & 0.6571 & 0.9363 \\
\hline
\end{tabular}




\section{Table 4}

\section{Average Investment and Cash Flow around Payout Tax Changes}

Panel A of this table shows the average investment for bottom and top quintiles of cash flow to assets around 14 payout tax increases (Average Tax C) in 1990-2008 of at least 3 percentage points and with at least 30 observations in the country-year. Panel B illustrates the difference in investment between top and bottom cash flow quintiles around 15 payout tax decreases. We measure investment by capital expenditure in year $t$ divided by the end-of-year $t-1$ assets. The table also shows the difference between groups and periods, and the difference-in-difference estimate. Standard errors are in parentheses. $* * *, * * *$ indicate statistical significance at $1 \%, 5 \%$, and $10 \%$ level, respectively. The 29 tax events are listed in Figure 4.

\begin{tabular}{|c|c|c|c|}
\hline \multicolumn{4}{|c|}{ Panel A: 14 Tax Increase Events } \\
\hline & Low Cash Flow Firms & High Cash Flow Firms & Difference between Groups \\
\hline & (1) & (2) & (3) \\
\hline \multirow{2}{*}{ Pre-reform Period ${ }_{t-4 ; t-1}$} & $-0.0230 * * *$ & $0.0307 * * *$ & $0.0533 * * *$ \\
\hline & $(0.0015)$ & $(0.0038)$ & $(0.0046)$ \\
\hline \multirow{2}{*}{ Post-reform Period ${ }_{t ; t+2}$} & $-0.0278 * *$ & $0.0481 * * *$ & $0.0759 * * *$ \\
\hline & $(0.0025)$ & $(0.0037)$ & $(0.0051)$ \\
\hline Difference between & $-0.0048^{*}$ & $0.0173 * * *$ & $0.0226 * * *$ \\
\hline Periods & $(0.0029)$ & $(0.0053)$ & $(0.0069)$ \\
\hline \multicolumn{4}{|c|}{ Panel B: 15 Tax Decrease Events } \\
\hline & Low Cash Flow Firms & High Cash Flow Firms & Difference between Groups \\
\hline & (1) & (2) & (3) \\
\hline \multirow[t]{2}{*}{ Pre-reform Period $_{\mathrm{t}-4 ; \mathrm{t}-1}$} & $-0.0232 * * *$ & $0.0495 * * *$ & $0.0727 * * *$ \\
\hline & $(0.0024)$ & $(0.0035)$ & $(0.0046)$ \\
\hline \multirow[t]{2}{*}{ Post-reform Period ${ }_{t ; t+2}$} & $-0.0163 * * *$ & $0.0390 * * *$ & $0.0554 * * *$ \\
\hline & $(0.0029)$ & $(0.0030)$ & $(0.0042)$ \\
\hline Difference between & $0.0068^{*}$ & $-0.0105 * *$ & $-0.0173 * * *$ \\
\hline Periods & $(0.0038)$ & $(0.0046)$ & $(0.0062)$ \\
\hline
\end{tabular}


Table 5

Firm Investment and Internal Resources under Various Tax Regimes

This table reports linear regression results for firm investment behavior, estimated over the 1990-2008 period. The dependent variable is Investment, defined as capital expenditure in year $t$ divided by the end-of-year $t-1$ assets. We use Cash Flow as a measure of firm's availability of internal resources for investment. Cash Flow is the ratio of cash flow in year $t$ relative to prior year total assets. See Table 3 for a description of the other independent variables included in the regressions. In column (1) we measure firms' tax burden on corporate payouts (Tax) as the personal income tax rate on dividends (Dividend Tax). Column (2) uses the country-weighted effective tax rate (Effective Tax C), and column (3) employs the country-weighted average tax rate (Average Tax C). Country-year interaction indicator variables are included in all specifications. Standard errors (shown in parentheses) allow for heteroskedasticity and are clustered by country-years. $* * *, * *, *$ indicate statistical significance at $1 \%, 5 \%$, and $10 \%$ level, respectively.

\begin{tabular}{|c|c|c|c|}
\hline & Dividend Tax Rate & $\begin{array}{l}\text { Country-Weighted } \\
\text { Effective Tax Rate }\end{array}$ & $\begin{array}{l}\text { Country-Weighted } \\
\text { Average Tax Rate }\end{array}$ \\
\hline & (1) & (2) & (3) \\
\hline Cash Flow*Tax & $\begin{array}{c}0.0009 * * \\
(0.0004)\end{array}$ & $\begin{array}{c}0.0021 * * * \\
(0.0006)\end{array}$ & $\begin{array}{c}0.0017 * * * \\
(0.0005) \\
\end{array}$ \\
\hline Cash Flow & $\begin{array}{c}0.0749 * * * \\
(0.0115)\end{array}$ & $\begin{array}{c}0.0644 * * * \\
(0.0101)\end{array}$ & $\begin{array}{c}0.0599 * * * \\
(0.0123)\end{array}$ \\
\hline Sales Growth & $\begin{array}{c}0.0157 * * * \\
(0.0011)\end{array}$ & $\begin{array}{c}0.0156^{* * *} \\
(0.0011)\end{array}$ & $\begin{array}{c}0.0156 * * * \\
(0.0011)\end{array}$ \\
\hline Leverage & $\begin{array}{l}0.0374 * * * \\
(0.0029)\end{array}$ & $\begin{array}{l}0.0373 * * * \\
(0.0029)\end{array}$ & $\begin{array}{l}0.0373 * * * \\
(0.0029)\end{array}$ \\
\hline Size & $\begin{array}{c}0.0025 \\
(0.0040)\end{array}$ & $\begin{array}{c}0.0031 \\
(0.0040)\end{array}$ & $\begin{array}{c}0.0030 \\
(0.0040)\end{array}$ \\
\hline Q & $\begin{array}{c}0.0011 * * * \\
(0.0001) \\
\end{array}$ & $\begin{array}{c}0.0011 * * * \\
(0.0001) \\
\end{array}$ & $\begin{array}{c}0.0010 * * * \\
(0.0001) \\
\end{array}$ \\
\hline Firm FE & Yes & Yes & Yes \\
\hline Country-year FE & Yes & Yes & Yes \\
\hline Observations & 81,222 & 81,222 & 81,222 \\
\hline R-squared & 0.5779 & 0.5781 & 0.5781 \\
\hline
\end{tabular}




\section{Table 6}

\section{Firm Investment and Internal Resources under Various Tax Regimes - Alternative Measures}

This table reports linear regression results for firm investment behavior, estimated over the 1990-2008 period. The dependent variable is Investment, defined as capital expenditure in year $t$ divided by the end-of-year $t-1$ assets. We use two alternative measures of firm's availability of internal resources for investment. Cash is defined as cash holdings over prior year assets (columns (1), (3), (5)). EBITDA measures earnings before interest, tax, and depreciation in year $t$ as a fraction of $t-1$ total assets (columns (2), (4), (6)). See Table 3 for a description of the other independent variables included in the regressions. In columns (1) and (2) we measure firms' tax burden on corporate payouts (Tax) as the personal income tax rate on dividends (Dividend Tax). Columns (3) and (4) use the country-weighted effective tax rate (Effective Tax C), and columns (5) and (6) employ the country-weighted average tax rate (Average Tax C). Countryyear interaction indicator variables are included in all specifications. Standard errors (shown in parentheses) allow for heteroskedasticity and are clustered by country-years. $* * *, * * *$ indicate statistical significance at $1 \%, 5 \%$, and $10 \%$ level, respectively.

\begin{tabular}{|c|c|c|c|c|c|c|}
\hline & \multicolumn{2}{|c|}{ Dividend Tax Rate } & \multicolumn{2}{|c|}{$\begin{array}{l}\text { Country-Weighted } \\
\text { Effective Tax Rate }\end{array}$} & \multicolumn{2}{|c|}{$\begin{array}{l}\text { Country-Weighted } \\
\text { Average Tax Rate }\end{array}$} \\
\hline & (1) & (2) & (3) & (4) & (5) & (6) \\
\hline Cash*Tax & $\begin{array}{c}0.0005 * * \\
(0.0002)\end{array}$ & & $\begin{array}{l}0.0006 * \\
(0.0003)\end{array}$ & & $\begin{array}{l}0.0005^{*} \\
(0.0002)\end{array}$ & \\
\hline EBITDA*Tax & & $\begin{array}{c}0.0003 \\
(0.0003) \\
\end{array}$ & & $\begin{array}{c}0.0010 * * \\
(0.0004)\end{array}$ & & $\begin{array}{c}0.0009 * * \\
(0.0003)\end{array}$ \\
\hline Cash & $\begin{array}{c}0.0014 \\
(0.0060)\end{array}$ & & $\begin{array}{c}0.0060 \\
(0.0054)\end{array}$ & & $\begin{array}{c}0.0028 \\
(0.0063)\end{array}$ & \\
\hline EBITDA & & $\begin{array}{c}0.0395 * * * \\
(0.0085)\end{array}$ & & $\begin{array}{c}0.0319 * * * \\
(0.0075)\end{array}$ & & $\begin{array}{c}0.0283 * * * \\
(0.0089)\end{array}$ \\
\hline Sales Growth & $\begin{array}{c}0.0213 * * \\
(0.0011)\end{array}$ & $\begin{array}{c}0.0188 * * * \\
(0.0012)\end{array}$ & $\begin{array}{c}0.0213 * * \\
(0.0011)\end{array}$ & $\begin{array}{c}0.0188 * * * \\
(0.0012)\end{array}$ & $\begin{array}{c}0.0213 * * \\
(0.0011)\end{array}$ & $\begin{array}{c}0.0188 * * * \\
(0.0012)\end{array}$ \\
\hline Leverage & $\begin{array}{l}0.0331 * * \\
(0.0030)\end{array}$ & $\begin{array}{c}0.0366^{* * *} \\
(0.0031)\end{array}$ & $\begin{array}{l}0.0331^{* *} \\
(0.0029)\end{array}$ & $\begin{array}{c}0.0366 * * * \\
(0.0030)\end{array}$ & $\begin{array}{l}0.0332 * * \\
(0.0029)\end{array}$ & $\begin{array}{c}0.0365 * * * \\
(0.0030)\end{array}$ \\
\hline Size & $\begin{array}{c}0.0062 \\
(0.0041)\end{array}$ & $\begin{array}{c}0.0038 \\
(0.0040)\end{array}$ & $\begin{array}{c}0.0060 \\
(0.0041)\end{array}$ & $\begin{array}{c}0.0042 \\
(0.0040)\end{array}$ & $\begin{array}{c}0.0062 \\
(0.0041)\end{array}$ & $\begin{array}{c}0.0041 \\
(0.0040)\end{array}$ \\
\hline Q & $\begin{array}{c}0.0013 * * \\
(0.0001)\end{array}$ & $\begin{array}{c}0.0013 * * * \\
(0.0001)\end{array}$ & $\begin{array}{c}0.0013 * * \\
(0.0001)\end{array}$ & $\begin{array}{c}0.0013 * * * \\
(0.0001) \\
\end{array}$ & $\begin{array}{c}0.0013 * * \\
(0.0001)\end{array}$ & $\begin{array}{c}0.0013 * * * \\
(0.0001)\end{array}$ \\
\hline Firm FE & Yes & Yes & Yes & Yes & Yes & Yes \\
\hline Country-year FE & Yes & Yes & Yes & Yes & Yes & Yes \\
\hline Observations & 81,222 & 81,222 & 81,222 & 81,222 & 81,222 & 81,222 \\
\hline R-squared & 0.5688 & 0.5707 & 0.5687 & 0.5708 & 0.5687 & 0.5708 \\
\hline
\end{tabular}


Table 7

\section{Firm Investment and Internal Resources under Various Tax Regimes -} Flexible Specifications

This table reports linear regression results for firm investment behavior, estimated over the 1990-2008 period. The dependent variable is Investment, defined as capital expenditure in year $t$ divided by the end-of-year $t-1$ assets. We use Cash Flow to measure firms' availability of internal resources for investment. Cash Flow is the ratio of cash flow in year $t$ relative to prior year total assets. See Table 3 for a description of the other independent variables included in the regressions. In column (1) we measure firms' tax burden on corporate payouts (Tax) as the personal income tax rate on dividends (Dividend Tax). Column (2) uses the country-weighted effective tax rate (Effective Tax C), and column (3) employs country-weighted average tax rate (Average Tax $C$ ). Country-year interaction indicator variables are included in all three specifications. We also include the interaction of Cash Flow with both country and year indicator variables. Standard errors (shown in parentheses) allow for heteroskedasticity and are clustered by country-years. ***, **, * indicate statistical significance at $1 \%, 5 \%$, and $10 \%$ level, respectively.

\begin{tabular}{|c|c|c|c|}
\hline & Dividend Tax Rate & $\begin{array}{l}\text { Country-Weighted } \\
\text { Effective Tax Rate }\end{array}$ & $\begin{array}{l}\text { Country-Weighted } \\
\text { Average Tax Rate }\end{array}$ \\
\hline & (1) & (2) & (3) \\
\hline Cash Flow*Tax & $\begin{array}{c}0.0011 * * \\
(0.0005)\end{array}$ & $\begin{array}{c}0.0027 * * * \\
(0.0008)\end{array}$ & $\begin{array}{c}0.0021 * * * \\
(0.0006) \\
\end{array}$ \\
\hline Sales Growth & $\begin{array}{c}0.0158^{* * *} \\
(0.0011)\end{array}$ & $\begin{array}{c}0.0157 * * * \\
(0.0011)\end{array}$ & $\begin{array}{c}0.0157 * * * \\
(0.0011)\end{array}$ \\
\hline Leverage & $\begin{array}{c}0.0373 * * * \\
(0.0029)\end{array}$ & $\begin{array}{c}0.0372 * * * \\
(0.0029)\end{array}$ & $\begin{array}{c}0.0372 * * * \\
(0.0029)\end{array}$ \\
\hline Size & $\begin{array}{c}0.0035 \\
(0.0040)\end{array}$ & $\begin{array}{c}0.0040 \\
(0.0040)\end{array}$ & $\begin{array}{c}0.0038 \\
(0.0040)\end{array}$ \\
\hline Q & $\begin{array}{c}0.0009 * * * \\
(0.0001)\end{array}$ & $\begin{array}{c}0.0009 * * * \\
(0.0001)\end{array}$ & $\begin{array}{c}0.0009 * * * \\
(0.0001)\end{array}$ \\
\hline Firm FE & Yes & Yes & Yes \\
\hline Country-year FE & Yes & Yes & Yes \\
\hline Year FE*CashFlow & Yes & Yes & Yes \\
\hline Country FE*CashFlow & Yes & Yes & Yes \\
\hline Observations & 81,222 & 81,222 & 81,222 \\
\hline R-squared & 0.5803 & 0.5805 & 0.5804 \\
\hline
\end{tabular}




\section{Table 8}

\section{External Equity Financing and Tax Regimes}

This table presents linear regression results for external financing behavior, estimated over the 1990-2008 period. The dependent variable is the value of new equity issues to start-of-year book value of assets. Observations where the dependent variable exceeds 0.15 are excluded. See Table 3 for a description of the independent variables included in the regressions. In column (1) we measure firms' tax burden on corporate payouts ( $\operatorname{Tax}$ ) as the personal income tax rate on dividends (Dividend Tax). Column (2) uses the country-weighted effective tax rate (Effective Tax C), and column (3) employs the country-weighted average tax rate (Average Tax C). Coefficient estimates are based on baseline specifications with country-fixed effects and year-fixed effects. Standard errors (shown in parentheses) are heteroskedasticity-robust and clustered by country-years. ***, $* *, *$ indicate statistical significance at $1 \%, 5 \%$, and $10 \%$ level, respectively.

\begin{tabular}{|c|c|c|c|}
\hline & Dividend Tax Rate & $\begin{array}{l}\text { Country-Weighted } \\
\text { Average Tax Rate }\end{array}$ & $\begin{array}{l}\text { Country-Weighted } \\
\text { Average Tax Rate }\end{array}$ \\
\hline & (1) & (2) & (3) \\
\hline Tax & $\begin{array}{c}-0.0001 * * * \\
(0.0000) \\
\end{array}$ & $\begin{array}{c}-0.0002 * * * \\
(0.0001) \\
\end{array}$ & $\begin{array}{c}-0.0002 * * * \\
(0.0001) \\
\end{array}$ \\
\hline Cash Flow & $\begin{array}{c}-0.0088 * * * \\
(0.0031)\end{array}$ & $\begin{array}{c}-0.0089 * * * \\
(0.0031)\end{array}$ & $\begin{array}{c}-0.0088 * * * \\
(0.0031)\end{array}$ \\
\hline $\begin{array}{l}\text { Stock Price } \\
\text { Appreciation }\end{array}$ & $\begin{array}{c}0.0112 * * * \\
(0.0009)\end{array}$ & $\begin{array}{c}0.0112 * * * \\
(0.0009)\end{array}$ & $\begin{array}{c}0.0112 * * * \\
(0.0009)\end{array}$ \\
\hline Sales Growth & $\begin{array}{c}0.0048 * * * \\
(0.0006)\end{array}$ & $\begin{array}{c}0.0047 * * * \\
(0.0006)\end{array}$ & $\begin{array}{c}0.0047 * * * \\
(0.0006)\end{array}$ \\
\hline Leverage & $\begin{array}{c}0.0085^{* * *} \\
(0.0017)\end{array}$ & $\begin{array}{c}0.0085^{* * *} \\
(0.0017)\end{array}$ & $\begin{array}{l}0.0085 * * * \\
(0.0017)\end{array}$ \\
\hline Size & $\begin{array}{c}0.0073 * * * \\
(0.0025)\end{array}$ & $\begin{array}{c}0.0072 * * * \\
(0.0025)\end{array}$ & $\begin{array}{c}0.0072 * * * \\
(0.0025)\end{array}$ \\
\hline Q & $\begin{array}{c}0.0006^{* * *} \\
(0.0001)\end{array}$ & $\begin{array}{c}0.0006^{* * *} \\
(0.0001)\end{array}$ & $\begin{array}{c}0.0006^{* * * *} \\
(0.0001)\end{array}$ \\
\hline Year FE & Yes & Yes & Yes \\
\hline Firm FE & Yes & Yes & Yes \\
\hline Observations & 33,280 & 33,280 & 33,280 \\
\hline R-squared & 0.3819 & 0.3815 & 0.3819 \\
\hline
\end{tabular}




\section{Table 9}

\section{Old and New View Firms and the Link between Payout Taxes and Cash Flow}

This table presents coefficient estimates for Cash Flow*Tax interaction using the country-weighted average tax rate (Average Tax C). We define firms as old view firms if predicted net proceeds from the sale/issue of common and preferred stock to lagged assets exceeds $2 \%$ (Panel A) or if previous years' sales of shares divided by lagged book assets exceeded zero (Panel B) or if the firm has low financial (using the Hadlock and Pierce Index of financial constraints). Firms with high financial constraints are defined as firms who are below median of firm age and firm size. We predict issues of common stock by common share free float, share turnover, sales growth, leverage, market capitalization and Tobin's q. $b$ is the coefficient estimate, (se) is the heteroskedasticity-robust standard error clustered by country-years, $t$ stat is the t-statistic of the significance of coefficient $b$, and $n$ is the number of observations. ***, **, * indicate statistical significance at $1 \%, 5 \%$, and $10 \%$ level, respectively.

\begin{tabular}{|c|c|c|c|c|}
\hline \multicolumn{5}{|c|}{ Panel A: Predicted Equity Issues } \\
\hline Category & $\mathrm{b}$ & (se) & [t-stat] & $\mathrm{N}$ \\
\hline $\begin{array}{l}\text { New view firms; } \\
\text { predicted equity issues }<2 \%\end{array}$ & 0.0012 & $(0.0009)$ & {$[1.36]$} & 21,781 \\
\hline $\begin{array}{l}\text { Old view firms; } \\
\text { predicted equity issues }>2 \%\end{array}$ & $0.0029 * * *$ & $(0.0009)$ & {$[3.12]$} & 19,137 \\
\hline \multicolumn{5}{|c|}{ Panel B: Previous year Equity Issues } \\
\hline Category & $\mathrm{b}$ & (se) & [t-stat] & $\mathrm{n}$ \\
\hline $\begin{array}{l}\text { New view firms; } \\
\text { last year equity issues }=0\end{array}$ & 0.0012 & $(0.0008)$ & {$[1.54]$} & 24,306 \\
\hline $\begin{array}{l}\text { Old view firms; } \\
\text { last year equity issues }>0\end{array}$ & $0.0027 * * *$ & $(0.0008)$ & {$[3.27]$} & 31,684 \\
\hline \multicolumn{5}{|c|}{ Panel C: Hadlock and Pierce Index of Financial Constraints } \\
\hline Category & $\mathrm{b}$ & $(\mathrm{se})$ & [t-stat] & $\mathrm{n}$ \\
\hline $\begin{array}{l}\text { New view firms; } \\
\text { low financial constraints }\end{array}$ & 0.0009 & $(0.0012)$ & {$[0.74]$} & 30,992 \\
\hline $\begin{array}{l}\text { Old view firms; } \\
\text { high financial constraints }\end{array}$ & $0.0026 * * *$ & $(0.0009)$ & [3.01] & 15,781 \\
\hline
\end{tabular}




\section{Table 10}

\section{Cash Flow Sensitivity of Cash and Tax Regimes}

This table presents linear regression results for cash holdings, estimated over the 1990-2008 period. The dependent variable is the change in the ratio of cash holdings to total assets. We measure firms' tax burden on corporate payouts as the personal income tax rate on dividends (Dividend Tax), the country-weighted effective tax rate (Effective Tax C), the country-weighted average tax rate (Average Tax C). Coefficient estimates are based on baseline specifications with country-fixed effects and year-fixed effects. Standard errors (shown in parentheses) are heteroskedasticity-robust and clustered by country-years. $* * *, * * *$ indicate statistical significance at $1 \%, 5 \%$, and $10 \%$ level, respectively.

\begin{tabular}{|c|c|c|c|c|c|c|}
\hline \multirow{4}{*}{ Tax*Cash Flow } & \multicolumn{3}{|c|}{$\begin{array}{l}\text { High Financial Constraints, No } \\
\text { Imputation System, and } \\
\text { Corporate Tax Advantage }>3 \%\end{array}$} & \multicolumn{3}{|c|}{$\begin{array}{l}\text { Low Financial Constraints, No } \\
\text { Imputation System, and } \\
\text { Corporate Tax Advantage }>3 \%\end{array}$} \\
\hline & DivTax & EffTaxC & AvgTaxC & DivTax & EffTaxC & AvgTaxC \\
\hline & $0.0048 * *$ & $0.0071 * *$ & $0.0067^{*}$ & 0.0032 & 0.0037 & 0.0025 \\
\hline & $(0.0023)$ & $(0.0034)$ & $(0.0035)$ & $(0.0026)$ & $(0.0031)$ & $(0.0025)$ \\
\hline \multirow[t]{2}{*}{ Cash Flow } & $0.1086^{*}$ & $0.1333 * *$ & 0.0948 & 0.0934 & $0.1181 * *$ & $0.1231 *$ \\
\hline & $(0.0617)$ & $(0.0552)$ & $(0.0662)$ & $(0.0791)$ & $(0.0562)$ & $(0.0630)$ \\
\hline Sales Growth & $\begin{array}{c}-0.0642 * * * \\
(0.0179)\end{array}$ & $\begin{array}{c}-0.0642 * * * \\
(0.0179)\end{array}$ & $\begin{array}{c}-0.0642 * * * \\
(0.0179)\end{array}$ & $\begin{array}{c}-0.0233 * * * \\
(0.0064)\end{array}$ & $\begin{array}{c}-0.0232 * * * \\
(0.0064)\end{array}$ & $\begin{array}{c}-0.0231^{* * *} \\
(0.0064)\end{array}$ \\
\hline \multirow[t]{2}{*}{$\Delta$ Leverage } & $0.1293 * * *$ & $0.1292 * * *$ & $0.1292 * * *$ & $0.1198 * * *$ & $0.1197 * * *$ & $0.1198 * * *$ \\
\hline & $(0.0293)$ & $(0.0292)$ & $(0.0293)$ & $(0.0151)$ & $(0.0150)$ & $(0.0150)$ \\
\hline \multirow[t]{2}{*}{ Size } & 0.0787 & 0.0743 & 0.0744 & -0.0145 & -0.0176 & -0.0193 \\
\hline & $(0.0555)$ & $(0.0545)$ & $(0.0540)$ & $(0.0224)$ & $(0.0238)$ & $(0.0238)$ \\
\hline \multirow[t]{2}{*}{ Q } & $0.0065 * * *$ & $0.0065 * * *$ & $0.0064 * * *$ & $0.0035 * * *$ & $0.0035^{* * *}$ & $0.0035^{* * *}$ \\
\hline & $(0.0021)$ & $(0.0021)$ & $(0.0021)$ & $(0.0012)$ & $(0.0012)$ & $(0.0012)$ \\
\hline Firm FE & Yes & Yes & Yes & Yes & Yes & Yes \\
\hline Country-Year FE & Yes & Yes & Yes & Yes & Yes & Yes \\
\hline Observations & 6,510 & 6,510 & 6,510 & 29,042 & 29,042 & 29,042 \\
\hline R-squared & 0.2831 & 0.2828 & 0.2830 & 0.1880 & 0.1878 & 0.1876 \\
\hline
\end{tabular}

\section{Table 11}

\section{Firm Investment and Internal Resources under Various Tax Regimes - Control for Corporate Income Tax}

This table replicates regressions for investment behavior from Table 4, estimated over the 1990-2008 period, but features the corporate tax rate as an additional explanatory variable for investment. Corporate Tax is the statutory tax rate on corporate income. We additionally interact CashFlow, CashFlow*CorporateTax, and CorporateTax with the indicator variable Imp, which is equal to 1 for imputation tax systems and zero otherwise. Baseline regression controls are as in Table 4. Country-year interaction indicator variables and interactions between the corporate tax rate and cash flow are included in all specifications. Standard errors (shown in parentheses) allow for heteroskedasticity and are clustered by country-years. $* *, * *, *$ indicate statistical significance at $1 \%, 5 \%$, and $10 \%$ level, respectively.

\begin{tabular}{lccc}
\hline & Dividend Tax Rate & $\begin{array}{c}\text { Country-Weighted } \\
\text { Average Tax Rate }\end{array}$ & $\begin{array}{c}\text { Country-Weighted } \\
\text { Average Tax Rate }\end{array}$ \\
\hline Cash Flow*Tax & $0.0007^{*}$ & $0.0012^{* *}$ & $0.0015^{* * *}$ \\
CashFlow* & $(0.0004)$ & $(0.0006)$ & $(0.0005)$ \\
CorporateTax & 0.0016 & 0.0016 & 0.0017 \\
CashFlow*Imp* & $(0.0013)$ & $(0.0014)$ & $(0.0014)$ \\
CorporateTax & $0.0048^{* *}$ & $0.0045^{* *}$ & $0.0044^{* *}$ \\
Baseline Controls & $(0.0019)$ & $(0.0020)$ & $(0.0020)$ \\
Firm FE & Yes & Yes & Yes \\
Country-year FE & Yes & Yes & Yes \\
Observations & Yes & Yes & 81,222 \\
R-squared & 81,222 & 81,222 & 0.5788 \\
\hline
\end{tabular}


Table 12

Impact of Taxation on the Cash Flow Sensitivity of Investment Robustness to Other Macroeconomic Determinants of Investment

This table reports coefficients for the cash flow*tax interaction in the linear regressions for firm investment behavior, estimated over the 1990-2008 period. Regression specifications are as in Table 5 but additional macroeconomic determinants of investment are included as controls. Those are Subsidies, Grants, Social Benefits, which include all government transfers on current account to private and public enterprises, and social security benefits in cash and in kind (Panel A); Military Expenditure as a fraction of GDP, which includes all current and capital expenditures on the armed forces (Panel B), Sales and Turnover Tax, which measure taxes on goods and services as a fraction of value added of industry and services (Panel C); and the $R \& D$ Expenditure as a fraction of GDP, which includes all expenditures for research and development covering basic research, applied research, and experimental development (Panel D). Standard errors (shown in parentheses) allow for heteroskedasticity and are clustered by country-years. ***, $* *, *$ indicate statistical significance at $1 \%, 5 \%$, and $10 \%$ level, respectively.

\begin{tabular}{|c|c|c|c|}
\hline & Dividend Tax Rate & $\begin{array}{l}\text { Country-Weighted } \\
\text { Effective Tax Rate }\end{array}$ & $\begin{array}{l}\text { Country-Weighted } \\
\text { Average Tax Rate }\end{array}$ \\
\hline & $(1)$ & (2) & (3) \\
\hline \multicolumn{4}{|c|}{ Panel A: Subsidies, Grants, Social Benefits } \\
\hline \multirow[t]{2}{*}{ Cash Flow *Tax } & 0.0012 & $0.0026^{* * *}$ & $0.0018 * *$ \\
\hline & $(0.0007)$ & $(0.0007)$ & $(0.0007)$ \\
\hline Observations & 41,577 & 41,577 & 41,577 \\
\hline R-squared & 0.6044 & 0.6048 & 0.6045 \\
\hline \multicolumn{4}{|c|}{ Panel B: Military Expenditure } \\
\hline \multirow[t]{2}{*}{ Cash Flow *Tax } & $0.0008 * *$ & $0.0021 * * *$ & $0.0016^{* * *}$ \\
\hline & $(0.0004)$ & $(0.0006)$ & $(0.0005)$ \\
\hline Observations & 81,222 & 81,222 & 81,222 \\
\hline R-squared & 0.5780 & 0.5781 & 0.5781 \\
\hline \multicolumn{4}{|c|}{ Panel C: Sales and Turnover Tax } \\
\hline \multirow[t]{2}{*}{ Cash Flow *Tax } & 0.0009 & $0.0024 * *$ & $0.0012 *$ \\
\hline & $(0.0007)$ & $(0.0010)$ & $(0.0007)$ \\
\hline Observations & 39,608 & 39,608 & 39,608 \\
\hline R-squared & 0.6019 & 0.6021 & 0.6019 \\
\hline \multicolumn{4}{|c|}{ Panel D: R\&D Expenditure } \\
\hline \multirow[t]{2}{*}{ Cash Flow *Tax } & 0.0004 & $0.0011 *$ & $0.0009 *$ \\
\hline & $(0.0003)$ & $(0.0005)$ & $(0.0005)$ \\
\hline Observations & 61,963 & 61,963 & 61,963 \\
\hline R-squared & 0.6128 & 0.6128 & 0.6128 \\
\hline
\end{tabular}


Table 13

\section{Firm Investment and Internal Resources under Various Tax Regimes - Control for Measurement Error in Q}

This table reports linear regression results for firm investment behavior, estimated over the 1990-2008 period. The dependent variable is Investment, defined as capital expenditure in year $t$ divided by the end-of-year $t-1$ assets. See Table 3 for a description of the other independent variables included in the regressions. In column (1) we use twice lagged Q as instrument for Q. Column (2) uses two lags of Q and CF as instruments. In Column (3) we use dynamic panel estimators from Arellano and Bond (1991). In Column (4) to (6) we use the Erickson and Whited (2002) higher order moment estimator and present results for the third, fifth and seventh moment. In specifications (1) to (3), we include firm- as well as country-year fixed effects. In specifications (4) to (6), we demeaned variables by country-year and by firm to account for our fixed effects. Baseline controls are included in all specifications. Standard errors (shown in parentheses) allow for heteroskedasticity. ${ }^{* *},{ }^{* *}, *$ indicate statistical significance at $1 \%, 5 \%$, and $10 \%$ level, respectively.

\begin{tabular}{|c|c|c|c|c|c|c|}
\hline & \multicolumn{2}{|c|}{ IV Estimation } & \multirow{2}{*}{$\begin{array}{c}\text { Arellano } \\
\text { and Bond } \\
\text { Estimator } \\
(3)\end{array}$} & \multicolumn{3}{|c|}{ EW Estimator } \\
\hline & $\begin{array}{l}Q_{t-2} \\
(1)\end{array}$ & $\begin{array}{c}\mathrm{Q}_{\mathrm{t}-2} \text { and } \mathrm{CF}_{\mathrm{t}-2} \\
(2)\end{array}$ & & $\begin{array}{c}\text { GMM3 } \\
(4) \\
\end{array}$ & $\begin{array}{l}\text { GMM5 } \\
(5)\end{array}$ & $\begin{array}{l}\text { GMM7 } \\
(6)\end{array}$ \\
\hline Dividend Tax Rate & $\begin{array}{c}0.0006^{* * *} \\
(0.0002)\end{array}$ & $\begin{array}{r}0.0007 * * * \\
(0.0002)\end{array}$ & $\begin{array}{c}0.0010 * * * \\
(0.0003)\end{array}$ & $\begin{array}{c}0.0006^{* *} \\
(0.0003)\end{array}$ & $\begin{array}{l}0.0005 * \\
(0.0003)\end{array}$ & $\begin{array}{c}0.0007 * * \\
(0.0003)\end{array}$ \\
\hline $\begin{array}{l}\text { Country-Weighted } \\
\text { Effective Tax Rate }\end{array}$ & $\begin{array}{c}0.0016^{* * *} \\
(0.0003)\end{array}$ & $\begin{array}{c}0.0017 * * * \\
(0.0003)\end{array}$ & $\begin{array}{c}0.0019 * * * \\
(0.0005)\end{array}$ & $\begin{array}{c}0.0015^{* * * *} \\
(0.0004)\end{array}$ & $\begin{array}{c}0.0013 * * * \\
(0.0004)\end{array}$ & $\begin{array}{c}0.0015 * * * \\
(0.0004)\end{array}$ \\
\hline $\begin{array}{l}\text { Country-Weighted } \\
\text { Average Tax Rate }\end{array}$ & $\begin{array}{c}0.0012 * * * \\
(0.0003)\end{array}$ & $\begin{array}{c}0.0013 * * * \\
(0.0003)\end{array}$ & $\begin{array}{c}0.0018 * * * \\
(0.0005)\end{array}$ & $\begin{array}{l}0.0011 * * \\
(0.0005)\end{array}$ & $\begin{array}{c}0.0009 * * \\
(0.0004)\end{array}$ & $\begin{array}{c}0.0012 * * * \\
(0.0004)\end{array}$ \\
\hline
\end{tabular}

